\title{
Genetic Diversity of Fusarium oxysporum f. sp. dianthi in Southern Spain
}

\author{
Raúl Castaño, ${ }^{1}$ Barbara Scherm, ${ }^{2}$ and Manuel Avilés ${ }^{1}$ \\ ${ }^{1}$ Department of Agroforestry Sciences, Escuela Técnica Superior de Ingenieríaa Agronómica (ETSIA), University of Seville, \\ Carretera de Utrera Km 1, 41013 Seville, Spain \\ ${ }^{2}$ Department of Plant Protection, University of Sassari, Via Enrico de Nicola 9, 07100 Sassari, Italy
}

Correspondence should be addressed to Raúl Castaño; rcasmun@gmail.com

Received 18 February 2014; Accepted 20 May 2014; Published 6 July 2014

Academic Editor: Praveen Rao Juvvadi

Copyright (C) 2014 Raúl Castaño et al. This is an open access article distributed under the Creative Commons Attribution License, which permits unrestricted use, distribution, and reproduction in any medium, provided the original work is properly cited.

\begin{abstract}
The diversity of races and prevalence of pathogenic populations of Fusarium oxysporum $\mathrm{f}$. sp. dianthi (Fod) were surveyed in an area in southern Spain. From 54 farms, 132 isolates were collected from wilted carnation plants. Isolates were characterized by RAPDPCR, DNA sequence analysis of the TEF1- $\alpha$ gene, and race-specific molecular markers. Selected isolates from RAPD groups were phenotypically evaluated by pathogenicity tests. Data analysis showed that Fod race 2 was the most frequent and prevalent race in the study area, followed by race $1 / 8$. Moreover, phylogenetic analyses showed similar results, which were different to those of the race-specific PCR assays. It was concluded that (i) seven isolates were not classified in groups where Fod testers were clustered; even they showed different results when race-specific markers were used, (ii) ten isolates with retarded race 1 or race 8 specific band were characterized as F. proliferatum by TEF1- $\alpha$ gene sequencing and clustered into an outgroup, and (iii) six isolates failed to generate an amplification signal using race-specific markers. Furthermore, three of them were grouped close to race 2 tester according to the phylogenetic analyses, showing the same differential pathogenicity as race 2 . This may indicate a Fod race 2 subgroup in this region.
\end{abstract}

\section{Introduction}

Fusarium oxysporum Schlechtend. Emend. W. C. Snyder \& H. N. Hans is a species complex of morphologically similar fungi with multiple phylogenetic origins that fall into three well-supported clades [1]. Pathogenic isolates of $F$. oxysporum often display a high degree of host specificity and can be subdivided into formae speciales on the basis of the plant species affected. The forma specialis dianthi (Fod) causes Fusarium wilt of carnation (Dianthus caryophyllus L.), a disease that is responsible for severe losses in areas where this flower is grown. The pathogen is widespread in soils worldwide [2-5].

In 2009, Andalusia accounted for $55.4 \%$ of the total carnations produced in Spain, and $62.1 \%$ of this was from the province of Cádiz [6], which is the greatest producer in Europe [7]. In this area, Fusarium wilt disease appeared five years after the introduction of the first carnation plants in 1975. Since then, it has been reported continuously [8].
Despite this, exhaustive studies on race diversity and pattern of Fod distribution in this area are lacking [5].

Fod can be distinguished into physiological races on the basis of the capacity of the pathogen to attack differential carnation cultivars. To date, ten races have been described worldwide [5]. Races 1 and 8 apparently originated in the Italian Riviera, where they are associated with Mediterranean carnation ecotypes found in Italy, France, and Spain. Race 2 is widespread in all areas of carnation cultivation in the world. Race 4 is found in carnation cultivars in the United States, Italy, Israel, Spain, and Colombia. Race 3 was initially classified as a Fod race, but DNA-based methods recently reclassified it as $F$. redolens, revealing that $F$. redolens and $F$. oxysporum not only are different species but also lack a sister group relationship [1]. The other races described have not been found in carnation crops in the Spanish areas studied so far [9].

Race classification of Fod can be established by testing its virulence using differential carnation cultivars $[4,5]$ or PCR 


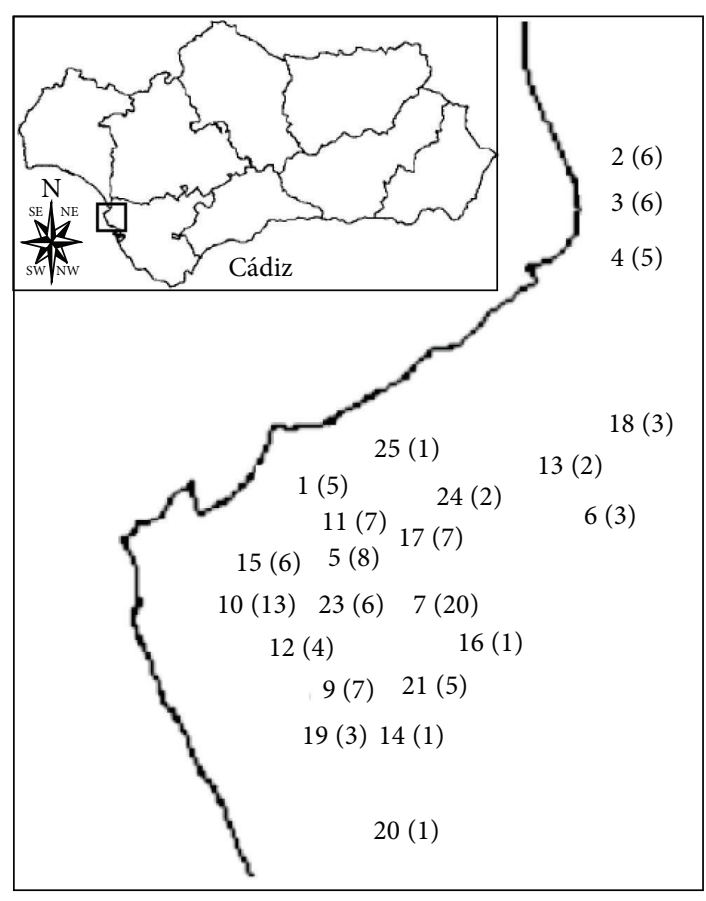

FIGURE 1: Wilted carnation plants collected in the north-west of the province of Cadiz. Top left: map of Andalusia showing the northwest area of the province of Cadiz. Bottom: the locations of some of the areas studied are represented in bold with code numbers and referenced in Table 1. In parentheses: numbers of isolates recovered in each zone.

with specific molecular markers to determine Fod races 2, 4, and, jointly, 1 and 8 [10]. Regarding race-specific primers, they were designed on the basis of transposable elements Fot1 and impala, whose restriction profiles show a race-associated polymorphic pattern using Southern hybridization [10]. Fingerprinting techniques (such as random amplification of polymorphic DNA polymerase chain reaction, RAPD-PCR) have been applied to evaluate the level of genetic diversity in various $F$. oxysporum formae speciales, including dianthi $[3,4,11]$. This technique can also separate Fod races $[4,11]$. Moreover, previous studies to establish a reliable molecular marker for phylogenetic studies on different Fusarium species have been conducted. The TEF1- $\alpha$ gene is considered highly informative for differentiating Fusarium spp. and many formae speciales within the F. oxysporum species complex [12-15]. These phylogenetic techniques could provide further information and reinforce the separation of Fod races using specific markers.

The determination of race and genetic diversity in pathogen populations in a given region provides relevant information of practical significance [16], which is useful for developing resistance breeding programs aimed at selecting cultivars that can reduce the devastating effects of Fusarium wilt in a given area $[17,18]$. The aim of this study was to survey the racial diversity and prevalence of a Fod population in the north-west of the Cádiz province, a region with a long tradition of carnation cultivation, using phenotypic and molecular assays.

\section{Materials and Methods}

2.1. Sampling Process. Wilted carnation plants were sampled from 54 randomly selected farms in three municipal areas of Andalucia, Spain (Chipiona, Sanlucar de Barrameda, and Rota) from 2004 to 2006 . One isolate was obtained from each disease focus in different greenhouses per farm. The sampling locations are shown in Table 1 and Figure 1.

2.2. Pathogen Isolation. Plants were cut at the stem base and the obtained pieces were surface-sterilized using $10 \%(\mathrm{v} / \mathrm{v})$ sodium hypochlorite for $2 \mathrm{~min}$. After two wash steps in sterile distilled water (SDW), the stem fragments were air-dried and transferred to Komada's Fusarium semiselective medium [19]. Plates were incubated at $25^{\circ} \mathrm{C}$ and fungi were monitored daily. Later, fungi were transferred to potato dextrose agar (PDA, Merck) plates. A total of 132 isolates displaying Fusarium morphology were recovered. Two monosporic cultures from each isolate were stored in silica gel at 5 to $10^{\circ} \mathrm{C}[20]$.

2.3. Total DNA Isolation. Fungi stored on silica gel were grown on sterile cellophane disk plates on PDA and incubated at $25^{\circ} \mathrm{C}$ for 7 to 8 days. Mycelium was recovered and transferred to a sterile Eppendorf tube. Tubes were frozen and then lyophilized (Telstar Cryodos, Telstar, UK) for $24 \mathrm{~h}$. Total genomic DNA was extracted from the lyophilized isolates as described by Cassago et al. [21], with minor modifications. Approximately $0.2 \mathrm{~g}$ of lyophilized mycelium was used. DNA was resuspended in $40 \mu \mathrm{L}$ of TE-Rnase $(10 \mu \mathrm{g} / \mathrm{mL})$ at $37^{\circ} \mathrm{C}$ for $30 \mathrm{~min}$. Concentration and purity of total DNA were determined by spectrophotometric measurements at $260 \mathrm{~nm}$ and $280 \mathrm{~nm}$.

2.4. RAPD-PCR Analysis. Population profiles were created by RAPD-PCR fingerprinting. Five 10-mer oligonucleotides were chosen on the basis of (i) previous genetic diversity studies with Fod and other F. oxysporum pathogens (OPB$01[22,23]$ and OPE-11 and OPE-16 [4]) and (ii) polymorphic band patterns (OPH-19 and OPH-20 (Operon Technologies, Alameda, CA, USA)).

The amplifications were performed in a total volume of $20 \mu \mathrm{L}$ containing $7.5 \mathrm{ng} \mu \mathrm{L}^{-1}$ of genomic DNA, 1x Biotools standard reaction buffer, $2.5 \mathrm{mM}$ of $\mathrm{MgCl}_{2}, 100 \mu \mathrm{M}$ of $\mathrm{dNTP}$ (Biotools, Madrid, Spain), $1 \mu \mathrm{M}$ of each primer, and $1 \mathrm{U}$ of Biotools DNA polymerase (Biotools, Madrid, Spain). The amplification conditions were as follows: a denaturation step for $5 \mathrm{~min}$ at $94^{\circ} \mathrm{C}$, followed by 45 amplification cycles of $30 \mathrm{~s}$ at $94^{\circ} \mathrm{C}, 1 \mathrm{~min}$ at $36^{\circ} \mathrm{C}$, and $2 \mathrm{~min}$ at $72^{\circ} \mathrm{C}$. A final extension step was performed for $5 \mathrm{~min}$ at $72^{\circ} \mathrm{C}$. Reactions were performed with a thermal cycler (Gene Amp PCR System 2700, Applied Biosystems). Amplified DNA products were run on $1.5 \%$ agarose gels and separated by electrophoresis and DNA was visualized and photographed under UV light with a Transilluminator (BioDoc-it System, UVP).

Each band in the RAPD profiles was considered an independent locus with two alleles and transformed into binary codes on the basis of presence versus absence of amplification products ( 1 for presence and 0 for absence). The amplification products of different primers recorded on photos were scored 
TABLE 1: Fusarium oxysporum populations from diseased carnation cultivars in the north-west of the province of Cadiz, ordered by farm.

\begin{tabular}{|c|c|c|c|c|c|c|}
\hline Isolate $^{a}$ & Municipal areas ${ }^{\mathrm{b}}$ & Zones $^{\mathrm{c}}$ & Code zone $^{\mathrm{d}}$ & Farm $^{\mathrm{e}}$ & Cultivar $^{\mathrm{e}}$ & Race $^{f}$ \\
\hline C4-06 & Chipiona & Espantamonos & 1 & $1 \mathrm{a}$ & Ashely & R1-8 \\
\hline $\mathrm{C} 8-13$ & Chipiona & Espantamonos & 1 & la & Ashely & R1-8 \\
\hline C8-15 & Chipiona & Espantamonos & 1 & $1 b$ & Bellami & $\mathrm{R} 2$ \\
\hline $\mathrm{C} 8-23$ & Chipiona & Espantamonos & 1 & $1 c$ & Pasodoble & $\mathrm{R} 1-8$ \\
\hline C9-06 & Chipiona & Espantamonos & 1 & $1 c$ & Pasodoble & R1-8 \\
\hline C4-10 & Sanlúcar de Barrameda & La Algaida & 2 & $2 \mathrm{a}$ & Rossini & $\mathrm{R} 2$ \\
\hline C9-21 & Sanlúcar de Barrameda & La Algaida & 2 & $2 \mathrm{a}$ & Rossini & $\mathrm{R} 2$ \\
\hline $\mathrm{C} 10-06$ & Sanlúcar de Barrameda & La Algaida & 2 & $2 \mathrm{a}$ & Rossini & $\mathrm{R} 2$ \\
\hline C7-04 & Sanlúcar de Barrameda & La Algaida & 2 & $2 b$ & Báltico & $\mathrm{R} 2$ \\
\hline C7-05 & Sanlúcar de Barrameda & La Algaida & 2 & $2 b$ & Delphi & $\mathrm{R} 2$ \\
\hline C9-24 & Sanlúcar de Barrameda & La Algaida & 2 & $2 b$ & Liberty & $\mathrm{R} 2$ \\
\hline C4-13 & Sanlúcar de Barrameda & La Algaida Punta del Muro & 3 & $3 a$ & Liberty & R1-8 \\
\hline C9-02 & Sanlúcar de Barrameda & La Algaida/Punta del Muro & 3 & $3 b$ & Liberty & $\mathrm{R} 2$ \\
\hline C9-10 & Sanlúcar de Barrameda & La Algaida/Punta del Muro & 3 & $3 b$ & Liberty & $\mathrm{R} 2$ \\
\hline C9-03 & Sanlúcar de Barrameda & La Algaida/Punta del Muro & 3 & $3 c$ & Ivana Orange & $\mathrm{R} 2$ \\
\hline C9-04 & Sanlúcar de Barrameda & La Algaida/Punta del Muro & 3 & $3 c$ & Ivana Orange & $\mathrm{R} 2$ \\
\hline C9-11 & Sanlúcar de Barrameda & La Algaida/Punta del Muro & 3 & $3 c$ & Ivana Orange & $\mathrm{R} 2$ \\
\hline C4-17 & Sanlúcar de Barrameda & La Algaida C/C & 4 & $4 \mathrm{a}$ & Gram Slam & $\mathrm{R} 1-8$ \\
\hline C4-18 & Sanlúcar de Barrameda & La Algaida C/C & 4 & $4 a$ & Gram Slam & R1-8 \\
\hline C10-08 & Sanlúcar de Barrameda & La Algaida $\mathrm{C} / \mathrm{C}$ & 4 & $4 a$ & Gram Slam & $\mathrm{R} 1-8$ \\
\hline C4-19 & Sanlúcar de Barrameda & La Algaida $\mathrm{C} / \mathrm{C}$ & 4 & $4 \mathrm{~b}$ & Orange Prestige & $\mathrm{R} 2$ \\
\hline C4-20 & Sanlúcar de Barrameda & La Algaida C/C & 4 & $4 \mathrm{~b}$ & Orange Prestige & R1-8 \\
\hline C4-21 & Chipiona & Los Rizos & 5 & $5 \mathrm{a}$ & Gaudina & $\mathrm{R} 1-8$ \\
\hline C4-22 & Chipiona & Los Rizos & 5 & $5 \mathrm{a}$ & Gaudina & R1-8 \\
\hline $\mathrm{C} 4-23$ & Chipiona & Los Rizos & 5 & $5 \mathrm{a}$ & Gaudina & $\mathrm{R} 1-8$ \\
\hline C5-01 & Chipiona & Los Rizos & 5 & $5 b$ & Liberty & $\mathrm{R} 2$ \\
\hline C5-16 & Chipiona & Los Rizos & 5 & $5 b$ & Liberty & $\mathrm{R} 2$ \\
\hline C6-21 & Chipiona & Los Rizos & 5 & $5 b$ & Liberty & $\mathrm{R} 2$ \\
\hline C5-05 & Chipiona & Los Rizos & 5 & $5 c$ & While Ashley & R1-8 \\
\hline C5-06 & Chipiona & Los Rizos & 5 & $5 c$ & While Ashley & R1-8 \\
\hline C5-03 & Sanlúcar de Barrameda & Hato de la Carne & 6 & $6 a$ & Barbara & R1-8 \\
\hline C5-04 & Sanlúcar de Barrameda & Hato de la Carne & 6 & $6 a$ & Barbara & R1-8 \\
\hline C6-23 & Sanlúcar de Barrameda & Hato de la Carne & 6 & $6 a$ & Barbara & $\mathrm{R} 1-8$ \\
\hline C5-07 & Chipiona & Las Machuelas & 7 & $7 a$ & Gaudina & R1-8 \\
\hline C5-08 & Chipiona & Las Machuelas & 7 & $7 a$ & Gaudina & $\mathrm{R} 1-8$ \\
\hline C5-09 & Chipiona & Las Machuelas & 7 & $7 a$ & Gaudina & R1-8 \\
\hline C5-19 & Chipiona & Las Machuelas & 7 & $7 \mathrm{~b}$ & Pilar & $\mathrm{R} 2$ \\
\hline C5-20 & Chipiona & Las Machuelas & 7 & $7 \mathrm{~b}$ & Pilar & $\mathrm{R} 2$ \\
\hline C5-24 & Chipiona & Las Machuelas & 7 & $7 \mathrm{~b}$ & Pilar & $\mathrm{R} 2$ \\
\hline C6-14 & Chipiona & Las Machuelas & 7 & $7 \mathrm{c}$ & Pilar & NB \\
\hline C6-15 & Chipiona & Las Machuelas & 7 & $7 \mathrm{c}$ & Pilar & NB \\
\hline C7-02 & Chipiona & Las Machuelas & 7 & $7 \mathrm{c}$ & Pilar & NB \\
\hline C7-08 & Chipiona & Las Machuelas & 7 & $7 d$ & Capineira & $\mathrm{R} 1-8$ \\
\hline C10-11 & Chipiona & Las Machuelas & 7 & $7 d$ & Capineira & R1-8 \\
\hline $\mathrm{C} 10-24$ & Chipiona & Las Machuelas & 7 & $7 d$ & Capineira & R1-8 \\
\hline C7-09 & Chipiona & Las Machuelas & 7 & $7 \mathrm{e}$ & Natila & R1-8 \\
\hline C9-07 & Chipiona & Las Machuelas & 7 & $7 \mathrm{e}$ & Natila & R1-8 \\
\hline C10-20 & Chipiona & Las Machuelas & 7 & $7 e$ & Natila & R1-8 \\
\hline C8-03 & Chipiona & Las Machuelas & 7 & $7 \mathrm{f}$ & Ticotico & $\mathrm{R} 2$ \\
\hline C8-04 & Chipiona & Las Machuelas & 7 & $7 \mathrm{f}$ & Ticotico & $\mathrm{R} 2$ \\
\hline C8-05 & Chipiona & Las Machuelas & 7 & $7 \mathrm{f}$ & Ticotico & $\mathrm{R} 2$ \\
\hline
\end{tabular}


TABle 1: Continued.

\begin{tabular}{|c|c|c|c|c|c|c|}
\hline Isolate $^{\mathrm{a}}$ & Municipal areas ${ }^{\mathrm{b}}$ & Zones $^{\mathrm{c}}$ & Code zone $^{\mathrm{d}}$ & Farm $^{\mathrm{e}}$ & Cultivar $^{\mathrm{e}}$ & Race $^{f}$ \\
\hline $\mathrm{C} 10-04$ & Chipiona & Las Machuelas & 7 & $7 f$ & Ticotico & R1-8 \\
\hline $\mathrm{C} 10-13$ & Chipiona & Las Machuelas & 7 & $7 \mathrm{~g}$ & Star & R1-8 \\
\hline C5-21 & Chipiona & Huerta San Juan & 8 & $8 a$ & Eveling & $\mathrm{R} 2$ \\
\hline C6-24 & Chipiona & Huerta San Juan & 8 & $8 \mathrm{a}$ & Eveling & $\mathrm{R} 2$ \\
\hline C9-20 & Chipiona & Huerta San Juan & 8 & $8 a$ & Eveling & $\mathrm{R} 2$ \\
\hline $\mathrm{C} 5-22$ & Chipiona & Majada de las vacas & 9 & $9 \mathrm{a}$ & Máster & NB \\
\hline C5-23 & Chipiona & Majada de las vacas & 9 & $9 a$ & Master & NB \\
\hline C5-25 & Chipiona & Majada de las vacas & 9 & $9 \mathrm{a}$ & Master & R1-8 \\
\hline C6-01 & Chipiona & Majada de las vacas & 9 & $9 a$ & Master & NB \\
\hline C6-03 & Chipiona & Majada de las vacas & 9 & $9 b$ & Pilar & $\mathrm{R} 2$ \\
\hline C6-04 & Chipiona & Majada de las vacas & 9 & $9 b$ & Pilar & $\mathrm{R} 2$ \\
\hline C6-07 & Chipiona & Majada de las vacas & 9 & $9 b$ & Pilar & $\mathrm{R} 2$ \\
\hline C6-06 & Chipiona & Escalereta & 10 & $10 \mathrm{a}$ & Báltico & $\mathrm{R} 2$ \\
\hline C6-08 & Chipiona & Escalereta & 10 & $10 \mathrm{a}$ & Báltico & $\mathrm{R} 2$ \\
\hline $\mathrm{C} 10-10$ & Chipiona & Escalereta & 10 & $10 \mathrm{a}$ & Báltico & $\mathrm{R} 2$ \\
\hline C6-09 & Chipiona & Escalereta & 10 & $10 \mathrm{~b}$ & Maestro & $\mathrm{R} 2$ \\
\hline C6-10 & Chipiona & Escalereta & 10 & $10 \mathrm{~b}$ & Maestro & $\mathrm{R} 2$ \\
\hline C6-25 & Chipiona & Escalereta & 10 & $10 \mathrm{~b}$ & Maestro & $\mathrm{R} 2$ \\
\hline C7-12 & Chipiona & Escalereta & 10 & $10 \mathrm{c}$ & Imagine & R1-8 \\
\hline C7-13 & Chipiona & Escalereta & 10 & $10 \mathrm{c}$ & Imagine & R1-8 \\
\hline C7-14 & Chipiona & Escalereta & 10 & $10 c$ & Imagine & $\mathrm{R} 2$ \\
\hline C7-17 & Chipiona & Escalereta & 10 & $10 \mathrm{c}$ & Imagine & $\mathrm{R} 2$ \\
\hline C7-20 & Chipiona & Escalereta & 10 & $10 \mathrm{c}$ & Imagine & R1-8 \\
\hline C9-18 & Chipiona & Escalereta & 10 & $10 \mathrm{c}$ & Imagine & $\mathrm{R} 2$ \\
\hline $\mathrm{C} 10-03$ & Chipiona & Escalereta & 10 & $10 \mathrm{c}$ & Imagine & $\mathrm{R} 2$ \\
\hline C6-11 & Chipiona & Pinar Martín & 11 & $11 \mathrm{a}$ & Berry & R1-8 \\
\hline C7-01 & Chipiona & Pinar Martín & 11 & $11 \mathrm{a}$ & Berry & R1-8 \\
\hline C6-12 & Chipiona & Pinar Martín & 11 & $11 b$ & Medea & R1-8 \\
\hline C6-13 & Chipiona & Pinar Martín & 11 & $11 b$ & Medea & $\mathrm{R} 2$ \\
\hline C8-10 & Chipiona & Pinar Martín & 11 & $11 \mathrm{c}$ & Rayo de Sole & $\mathrm{R} 2$ \\
\hline C8-11 & Chipiona & Pinar Martín & 11 & $11 \mathrm{c}$ & Rayo de Sole & $\mathrm{R} 2$ \\
\hline C10-05 & Chipiona & Pinar Martín & 11 & $11 \mathrm{c}$ & Rayo de Sole & R1-8 \\
\hline C6-16 & Chipiona & El Olivar & 12 & $12 \mathrm{a}$ & Dover & $\mathrm{R} 2$ \\
\hline C6-17 & Chipiona & El Olivar & 12 & $12 \mathrm{a}$ & Dover & $\mathrm{R} 2$ \\
\hline C7-03 & Chipiona & El Olivar & 12 & $12 \mathrm{a}$ & Dover & $\mathrm{R} 2$ \\
\hline C11-03 & Chipiona & El Olivar & 12 & $12 \mathrm{~b}$ & Arena & $\mathrm{R} 2$ \\
\hline C7-06 & Sanlúcar de Barrameda & Madre del Agua & 13 & $13 \mathrm{a}$ & Firato & $\mathrm{R} 2$ \\
\hline $\mathrm{C} 10-17$ & Sanlúcar de Barrameda & Madre del Agua & 13 & $13 \mathrm{a}$ & Firato & $\mathrm{R} 2$ \\
\hline C7-11 & Chipiona & Majadales & 14 & $14 \mathrm{a}$ & Tempo & $\mathrm{R} 2$ \\
\hline C7-16 & Chipiona & Los Llanos & 15 & $15 \mathrm{a}$ & Lolita & $\mathrm{R} 2$ \\
\hline C7-18 & Chipiona & Los Llanos & 15 & $15 \mathrm{a}$ & Lolita & $\mathrm{R} 2$ \\
\hline C11-04 & Chipiona & Los Llanos & 15 & $15 \mathrm{a}$ & Lolita & $\mathrm{R} 2$ \\
\hline $\mathrm{C} 10-14$ & Chipiona & Los Llanos/Envidio & 15 & $15 b$ & Claudia & R1-8 \\
\hline $\mathrm{C} 10-15$ & Chipiona & Los Llanos/Envidio & 15 & $15 b$ & Claudia & R1-8 \\
\hline $\mathrm{C} 10-16$ & Chipiona & Los Llanos/Envidio & 15 & $15 b$ & Claudia & R1-8 \\
\hline $\mathrm{C} 8-02$ & Chipiona & Cerro Colón & 16 & $16 \mathrm{a}$ & Delfi & $\mathrm{R} 2$ \\
\hline C8-06 & Chipiona & Loma Baja & 17 & $17 \mathrm{a}$ & Splendido & $\mathrm{R} 2$ \\
\hline C8-07 & Chipiona & Loma Baja & 17 & $17 \mathrm{a}$ & Splendido & $\mathrm{R} 2$ \\
\hline C8-08 & Chipiona & Loma Baja & 17 & $17 \mathrm{a}$ & Splendido & R1-8 \\
\hline C8-09 & Chipiona & Loma Baja & 17 & $17 \mathrm{a}$ & Splendido & R1-8 \\
\hline C8-19 & Chipiona & Loma Baja & 17 & $17 \mathrm{~b}$ & Eilat & $\mathrm{R} 2$ \\
\hline
\end{tabular}


TABLE 1: Continued.

\begin{tabular}{|c|c|c|c|c|c|c|}
\hline Isolate $^{\mathrm{a}}$ & Municipal areas ${ }^{\mathrm{b}}$ & Zones $^{c}$ & Code zone $^{\mathrm{d}}$ & Farm $^{e}$ & Cultivare $^{\mathrm{e}}$ & Race $^{f}$ \\
\hline $\mathrm{C} 8-20$ & Chipiona & Loma Baja & 17 & $17 b$ & Eilat & $\mathrm{R} 2$ \\
\hline C8-24 & Chipiona & Loma Baja & 17 & $17 \mathrm{~b}$ & Eilat & $\mathrm{R} 2$ \\
\hline $\mathrm{C} 8-22$ & Sanlúcar de Barrameda & Santa Tecla & 18 & $18 \mathrm{a}$ & Montezuma & $\mathrm{R} 2$ \\
\hline C8-14 & Sanlúcar de Barrameda & Santa Tecla & 18 & $18 \mathrm{~b}$ & Tauroc & $\mathrm{R} 1-8$ \\
\hline C9-05 & Sanlúcar de Barrameda & Santa Tecla & 18 & $18 \mathrm{~b}$ & Tauroc & R1-8 \\
\hline $\mathrm{C} 8-21$ & Chipiona & Majadales alto & 19 & $19 \mathrm{a}$ & Solar Oro & $\mathrm{R} 1-8$ \\
\hline C9-17 & Chipiona & Majadales alto & 19 & $19 b$ & White Fleurette & R1-8 \\
\hline C11-02 & Chipiona & Majadales alto & 19 & $19 c$ & Millenium & $\mathrm{R} 2$ \\
\hline C9-08 & Rota & Peña del Águila & 20 & $20 \mathrm{a}$ & Rebeca & R1-8 \\
\hline C4-01 & Chipiona & Aulagar & 21 & $21 \mathrm{a}$ & Pink Ashley & $\mathrm{R} 2$ \\
\hline C4-02 & Chipiona & Aulagar & 21 & $21 \mathrm{a}$ & Pink Ashley & $\mathrm{R} 2$ \\
\hline C4-03 & Chipiona & Aulagar & 21 & $21 \mathrm{a}$ & Pink Ashley & $\mathrm{R} 2$ \\
\hline C4-04 & Chipiona & Aulagar & 21 & $21 b$ & Pink Ashley & $\mathrm{R} 2$ \\
\hline C7-10 & Chipiona & Aulagar & 21 & $21 b$ & Pink Ashley & $\mathrm{R} 2$ \\
\hline C4-14 & Chipiona & Monteruco & 22 & $22 \mathrm{a}$ & Cerise R. Barb. & R1-8 \\
\hline C4-15 & Chipiona & Monteruco & 22 & $22 \mathrm{a}$ & Cerise R. Barb. & R1-8 \\
\hline C4-16 & Chipiona & Monteruco & 22 & $22 \mathrm{a}$ & Cerise R. Barb. & R1-8 \\
\hline C10-07 & Chipiona & Monteruco & 22 & $22 \mathrm{a}$ & Cerise R. Barb. & R1-8 \\
\hline C7-07 & Chipiona & Monteruco & 22 & $22 b$ & Orbit & R1-8 \\
\hline C9-14 & Chipiona & Monteruco & 22 & $22 b$ & Orbit & R1-8 \\
\hline C9-25 & Chipiona & Monteruco & 22 & $22 b$ & Orbit & R1-8 \\
\hline C7-21 & Chipiona & Lopina & 23 & $23 a$ & Nogalte & $\mathrm{R} 2$ \\
\hline C7-22 & Chipiona & Lopina & 23 & $23 a$ & Nogalte & $\mathrm{R} 2$ \\
\hline C7-23 & Chipiona & Lopina & 23 & $23 a$ & Nogalte & $\mathrm{R} 2$ \\
\hline C7-24 & Chipiona & Lopina & 23 & $23 a$ & Nogalte & $\mathrm{R} 2$ \\
\hline C7-25 & Chipiona & Lopina & 23 & $23 a$ & Nogalte & $\mathrm{R} 2$ \\
\hline C8-01 & Chipiona & Lopina & 23 & $23 a$ & Nogalte & $\mathrm{R} 2$ \\
\hline C9-15 & Chipiona & La Loma & 24 & $24 a$ & Spectro & R1-8 \\
\hline C9-19 & Chipiona & La Loma & 24 & $24 b$ & Spectro & R1-8 \\
\hline C10-02 & Chipiona & Copina & 25 & $25 a$ & Delphi & $\mathrm{R} 2$ \\
\hline
\end{tabular}

${ }^{a}$ Names of population isolates

${ }^{\mathrm{b}}$ Municipal areas (Chipiona, Sanlúcar de Barrameda, and Rota)

${ }^{\mathrm{c}}$ Zones in which farms were studied

${ }^{\mathrm{d}} \mathrm{A}$ random code assigned to each zone

${ }^{\mathrm{e}}$ Carnation cultivar finding in the corresponding farm, which isolates were obtained. Code zone with the same number but different letters means same zone but different farms

${ }^{\mathrm{f}}$ Fusarium oxysporum f. sp. dianthi (Fod) determination using specific primers [10]. R1-8: Fod race 1 or race 8; R2: Fod race 2; R1-8 in bold: retarded electrophoretic mobility band; NB: nonamplified band.

manually and a binary matrix was thus generated [24]. Fortyone markers were analyzed using five operon primers. From the binary data matrix, the distances were estimated using the distance estimation method described by Link et al. [25], using TREECON [26] of the Windows software package. Tree topology was inferred with the UPGMA (unweighted paired group method with arithmetic averages) clustering method to construct an unrooted tree [24]. Amplifications were repeated once with each monosporic culture from each isolate.

2.5. Isolate Determination by DNA Sequencing. A portion of the translation elongation factor 1- $\alpha$ gene $(T E F 1-\alpha)$ was amplified using EF1 and EF2 primers. Each $50 \mu \mathrm{L}$ of PCR reaction contained $7.5 \mathrm{ng} \mu \mathrm{L}^{-1}$ of genomic DNA, 1x Biotools standard reaction buffer, $3.75 \mathrm{mM}$ of $\mathrm{MgCl}_{2}, 100 \mu \mathrm{M}$ of dNTP (Biotools, Madrid, Spain), $0.5 \mu \mathrm{M}$ of each primer, and $1 \mathrm{U}$ of Biotools Pfu DNA polymerase (Biotools, Madrid, Spain). The PCR for both primer pairs was run at $95^{\circ} \mathrm{C}$ for $2 \mathrm{~min}$, followed by 10 cycles of $94^{\circ} \mathrm{C}$ for $1 \mathrm{~min}, 54^{\circ} \mathrm{C}$ for $2 \mathrm{~min}$, and an elongation phase at $72^{\circ} \mathrm{C}$ for $2 \mathrm{~min}$, and 20 cycles of $94^{\circ} \mathrm{C}$ for $1 \mathrm{~min}, 54^{\circ} \mathrm{C}$ for $2 \mathrm{~min}$, and an elongation phase at $72^{\circ} \mathrm{C}$ for 2 min with an increase of $4 \mathrm{~s}$ per cycle, concluded by a final elongation phase at $72^{\circ} \mathrm{C}$ for $5 \mathrm{~min}$. Reactions were performed with a thermal cycler (Gene Amp PCR System 2700, Applied Biosystems). Amplified DNA products were run on 1.5\% agarose gels and DNA was photographed under UV light, as described previously. The expected amplification product size was $700 \mathrm{bp}$. PCR products were purified using Speedtools PCR Clean-Up Kit (Biotools, Madrid, Spain). Sequencing was performed by Secugen (Secugen, Madrid, Spain). 
TABLE 2: Response of five carnation cultivars tested to races 1, 2, 4, 6, and 8 of Fusarium oxysporum f. sp. dianthi.

\begin{tabular}{lccccc}
\hline & Race 1 & Race 2 & Race 4 & Race 6 & Race 8 \\
\hline Eilat & $\mathrm{R}$ & $\mathrm{S}$ & $\mathrm{R}$ & $\mathrm{R}$ & $\mathrm{R}$ \\
New Elsy & $\mathrm{S}$ & $\mathrm{R}$ & $\mathrm{R}$ & $\mathrm{R}$ \\
Suprema & $\mathrm{R}$ & $\mathrm{S}$ & $\mathrm{NT}$ & $\mathrm{NT}$ \\
Reina & $\mathrm{R}$ & $\mathrm{S}$ & $\mathrm{R}$ & $\mathrm{NT}$ & $\mathrm{R}$ \\
Mayor & $\mathrm{S}$ & $\mathrm{S}$ & $\mathrm{NT}$ & $\mathrm{S}$ \\
\hline
\end{tabular}

R: resistant; S: susceptible; NT: not tested.

TABLE 3: Selected isolates from the RAPD study.

\begin{tabular}{|c|c|c|c|c|c|c|}
\hline Isolate $^{\mathrm{a}}$ & $\begin{array}{c}\text { Municipal } \\
\text { area }^{b}\end{array}$ & Species name $e^{c}$ & Race $^{\mathrm{d}}$ & $\begin{array}{l}\text { RAPD } \\
\text { Group }\end{array}$ & $\begin{array}{l}\text { TEF } \\
\text { Group }\end{array}$ & $\begin{array}{l}\text { GenBank } \\
\text { accession }^{\mathrm{e}}\end{array}$ \\
\hline C5-20 & Chipiona & F. oxysporum & 2 & I & I & GU199330 \\
\hline C6-15 & Chipiona & F. oxysporum & NB & I & I & GU199333 \\
\hline C6-25 & Chipiona & F. oxysporum & 2 & $\mathrm{I}$ & I & GU226824 \\
\hline C9-10 & Sanlúcar de B. & F. oxysporum & 2 & II & I & GU226828 \\
\hline C5-23 & Chipiona & F. oxysporum & NB & IV & IV & GU199331 \\
\hline C6-01 & Chipiona & F. oxysporum & NB & IV & IV & GU199332 \\
\hline C10-07 & Chipiona & F. oxysporum & $1-8$ & $\mathrm{~V}$ & IV & GU226826 \\
\hline C8-08 & Chipiona & F. oxysporum & $\mathrm{RB}$ & VI & IV & GU226825 \\
\hline C4-17 & Sanlúcar de B. & F. oxysporum & $1-8$ & VII & III & GU199328 \\
\hline C4-22 & Chipiona & F. oxysporum & $1-8$ & VIII & III & GU199329 \\
\hline C10-14 & Chipiona & F. oxysporum & $1-8$ & VIII & III & GU226827 \\
\hline C4-15 & Chipiona & F. proliferatum & $\mathrm{RB}$ & IX & $\mathrm{V}$ & GU191842 \\
\hline $\mathrm{R} 1$ & $\begin{array}{l}\text { Marismas de } \\
\text { Lebrija }\end{array}$ & F. oxysporum & $1-8$ & VIII & III & \\
\hline R2 & Chipiona & F. oxysporum & 2 & I & I & \\
\hline $\mathrm{R} 4$ & Italy & F. oxysporum & 4 & III & II & \\
\hline R8 & Italy & F. oxysporum & $1-8$ & VIII & III & \\
\hline $\mathrm{Fr}$ & South África & F. redolens & - & - & - & \\
\hline
\end{tabular}

Sequences were edited and then blasted against the GenBank database (http://blast.ncbi.nlm.nih.gov/Blast.cgi). To match the TEF1- $\alpha$ gene in conjunction with GenBank, the Fusarium-ID database (http://fusarium.cbio.psu.edu) was used. This database is publicly available and contains vouchered and well-characterized sequences of Gibberella fujikuroi, F. oxysporum, and F. solani species [15]. Accession numbers of TEF1- $\alpha$ regions from selected isolates are shown in Table 3.

2.6. Phylogenetic Distance Tree Using TEF1- $\alpha$ Gene Sequences. Sequences were edited using Sequence Scanner v1.0 software (Applied Biosystems) and aligned to construct a phylogenetic tree using the MEGA5 software [27]. Evolutionary history was inferred from the maximum likelihood method based on the Kimura 2-parameter model [28]. The tree with the highest log-likelihood $(-1413.6427)$ is shown. The percentage of trees in which the associated taxa clustered together is shown next to the branches. Initial tree(s) for the heuristic search (Close-Neighbor-Interchange algorithm) were obtained automatically as follows. When the number of common sites was $<100$ or less than one fourth of the total number of sites, the maximum parsimony method was used; otherwise, the BIONJ method with a maximum composite likelihood (MCL) distance matrix was used. The tree was drawn to scale, with branch lengths measured in the number of substitutions per site. The analysis involved 137 nucleotide sequences. All positions containing gaps and missing data were eliminated. There were a total of 640 positions in the final dataset.

2.7. Bacterial, F. redolens, and Fod Race-Specific PCR Assays. Bacterial 16S rDNA was used to control the presence and accessibility of eubacterial DNA, which could amplify false RAPD markers. For this purpose, $704 \mathrm{f}$ and $1495 \mathrm{r}$ primers [29] were used. Specific Fusarium redolens (Fr) primers, redolens$\mathrm{F}$, and redolens- $\mathrm{R}$ [1], were used to detect the presence of this pathogen in the population. Fod races were determined using 
a multiplex PCR with race-specific primers (Ft3f, IMP2f, R8.1r, R2.1r, and R4.2r) designed by Chiocchetti et al. [10]. Primers were obtained from cVIRAL (Alcobendas, Madrid, Spain). Negative and positive controls were included in all experiments. The bacterial isolate 911 (Collection of Dr. M. Aviles, University of Seville, Spain), F. redolens (provided by Dr. E.T. Steenkamp, University of Pretoria, Pretoria, South Africa), and the Fod race testers (provide by Dr. J.M. Melero, CSIC, Córdoba, Spain) were used as positive controls for each PCR assay.

Twenty microliters of reaction volume containing $7.5 \mathrm{ng} \mu \mathrm{L}^{-1}$ of genomic DNA, 1x Biotools standard reaction buffer, $2.5 \mathrm{mM}$ of $\mathrm{MgCl}_{2}, 100 \mu \mathrm{M}$ of dNTP (Biotools, Madrid, Spain), and $1 \mathrm{U}$ of Biotools DNA polymerase (Biotools, Madrid, Spain) were used. Primers were added as follows: $0.5 \mu \mathrm{M}$ each for eubacterial DNA detection [29], $0.5 \mu \mathrm{M}$ each for Fr detection [1], and $2.5 \mu \mathrm{M}$ each for race determination [10]. Reactions were performed with a thermal cycler (Gene Amp PCR System 2700, Applied Biosystems) following the respective authors' protocols. After amplification, the reaction mixture was loaded onto a $1.5 \%$ agarose gel and photographed under UV light as described previously. The expected amplification product sizes were $800 \mathrm{bp}$ for eubacteria, 386 bp for Fr, and 295, 564, and 1315 bp for Fod races $1 / 8$, race 2 , and race 4 , respectively. Analyses were repeated one with each monosporic culture from each isolate.

2.8. Fusarium Wilt Pathogenicity Test. Determination of race is based on the response of the different cultivars to a particular isolate. For this phenotypic assay, at least one isolate of each RAPD group was selected on the basis of the similarity index after the fingerprinting study $[9,16,23]$. Pathogenicity test was performed with five different carnation (D. caryophyllus) cultivars (Reina, New Elsy, Mayor, Suprema, and Eilat; summarized response in Table 2) in a greenhouse in Seville (Seville, Spain) from June to August 2009. Plants were provided by Barberet \& Blanc (Murcia, Spain) as bare-root cuttings (8 to 12 true-leaf stages). Fungi were grown for 7 to 10 days on AMAP $\left(10 \mathrm{~g} \mathrm{~L}^{-1}\right.$ agar, $10 \mathrm{~g} \mathrm{~L}^{-1}$ malt extract (Difco, Le Pont de Claix, France), and $2 \mathrm{gL}^{-1}$ asparagine (Difco, Le Pont de Claix, France)) plates at $25^{\circ} \mathrm{C}$. Five $\mathrm{mL}$ of SDW were added to the plates and the surface was scraped with a sterile spatula. Inocula were filtered through two layers of sterile gauze. The concentration of conidia was determined with a hemocytometer and then diluted in SDW to give suspensions of $10^{6}$ conidia $\mathrm{mL}^{-1}$. These suspensions were used to inoculate carnation cuttings by root dipping for $30 \mathrm{~min}$ using 50 to $80 \mathrm{~mL}$ per plant. Controls were carried out by dipping plant roots in sterile water. Inoculated cuttings were individually planted in pots containing peat fertilized with $0.5 \mathrm{~g} \mathrm{~L}^{-1}$ of Peter's Foliar Feed $\left(27+15+12 ; \mathrm{N}+\mathrm{P}_{2} \mathrm{O}_{5}+\right.$ $\mathrm{K}_{2} \mathrm{O}$, and micronutrients; Scotts, Heerlen, the Netherlands) and $0.5 \mathrm{~g} \mathrm{~L}^{-1}$ of Fertigreen (Burés, Barcelona, Spain). The experimental design involved five plants for each isolate and cultivar combination, randomized within each cultivar.

Disease severity was scored using the symptom severity scale described by Baayen and van der Plas [30] as follows:
$0=$ asymptomatic plant ( $0 \%$ disease); $1=$ weakly affected plant (5\%); 2 = local base-stem symptoms (20\%); $3=$ unilateral and well-developed symptoms (50\%); 4 = strong disease symptoms throughout the plant $(80 \%) ; 5=$ dead plant (100\%). Disease severity was monitored twice a week. At each assessment, the mean disease severity per pot was calculated. The standardized area under the disease progress curve (AUDPC) was calculated by disease severity integrated between symptom onset and the final time of the assay and divided by the total duration (days) of the epidemic in each bioassay. Therefore, AUDPC data can range from 0 to 1 . High severity was considered when AUDPC was higher than 0.45. Moderate severity was considered when AUDPC data range between 0.45 and 0.30 and low severity was considered when AUDPC data range between 0.30 and 0.20 . Pathogenicity test was repeated twice. Each test lasted three months.

2.9. Statistical Analyses. Data collected from the pathogenicity bioassay were analyzed with the Statgraphics Plus program (version 5.1; Statistical Graphics Corp., Rockville, MD). Data were analyzed using one-way ANOVA. The means were compared using Tukey's test $(P<0.05)$.

\section{Results}

3.1. Classification of Isolates Using RAPD Analysis. All isolates were independently subjected to RAPD-PCR analysis employing five random decamer primers. In the preliminary experiments, all the tested primers produced distinct and reproducible band profiles (Figure 2). Reproducible markers were used in cluster analysis. On the basis of a similarity matrix, a dendrogram using the UPGMA was constructed to illustrate the level of similarity among isolates (Figure 3(a)). According to the patterns of all five primers, isolates were classified into nine RAPD groups "haplogroups," corresponding to a similarity of more than $90 \%$. Each RAPD group showed high genetic homogeneity.

Distance-based analyses of the RAPD groups are shown in Figure 3(a). Cluster analysis separated the Fod race testers with an approximately $60 \%$ similarity index, with a bootstrap support of $93 \%$. Seventy-three isolates (plus the Fod race 2 tester) were placed in RAPD group I. The RAPD group II showed one isolate (C9-10), while Fod race 4 was clustered in RAPD group III (Figure 3(a)). Between RAPD groups III and VII, seven isolates were clustered in three distinct groups (RAPD groups IV, V, and VI), The RAPD group VII showed only one isolate (C7-14). Forty isolates were clustered in RAPD group VIII, together with the Fod races 1 and 8 testers. Finally, ten isolates were outgroups (Figure 3(a)) and clustered in RAPD group IX; F. redolens was also clustered as an outgroup, closer to RAPD group IX.

3.2. Phylogeny Using the TEF1- $\alpha$ Sequence. Phylogenetic analysis of the partial TEF1- $\alpha$ gene from all isolates (Figure 3(b)) revealed five groups and F. redolens as an outgroup. The Fod race 2 tester was found in TEF group I, along with 74 isolates (the same as RAPD groups I and II). Race 4 tester, as in RAPD analysis, was the only one to cluster in TEF group II. Races 1 and 8 testers and 41 isolates (the same as RAPD groups VII 


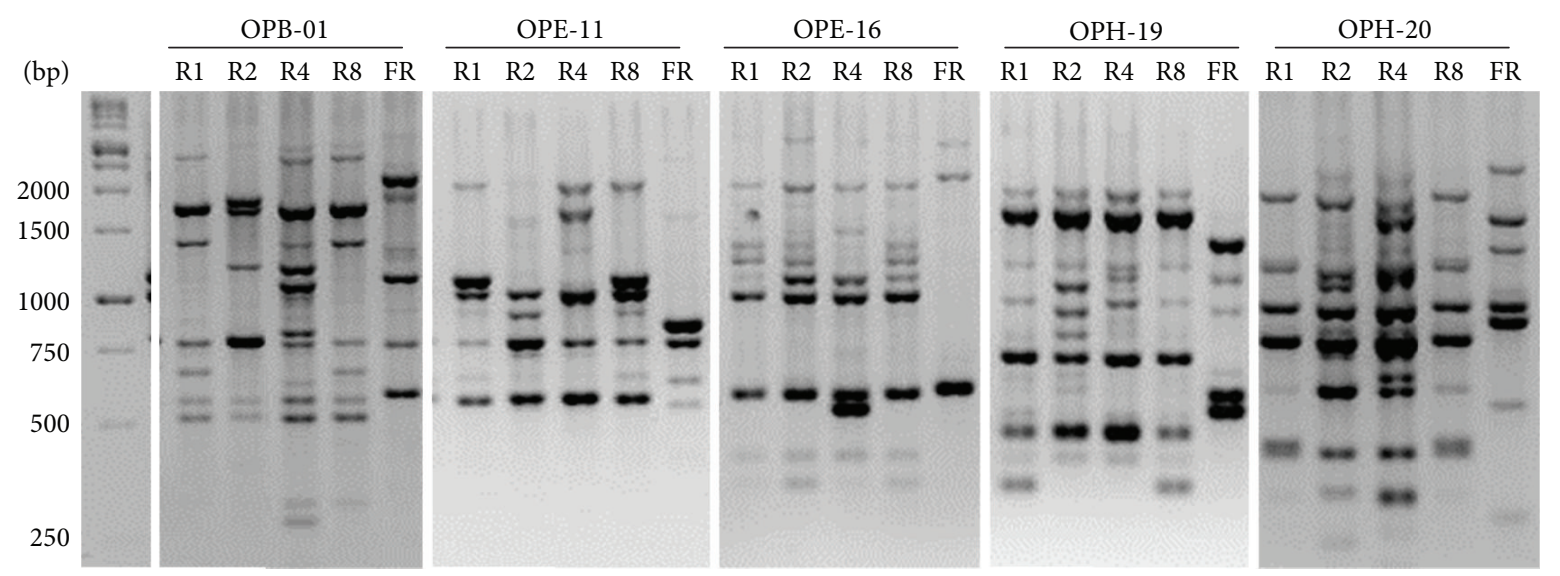

FIGURE 2: Random amplified polymorphisms DNA (RAPD) patterns of the different Fod race testers and one F. redolens obtained with five primers. Left: molecular weight marker (1 kb DNA ladder). Races belonging to R1: Fod race 1, R2: Fod race 2, R4: Fod race 4, R8: Fod race 8, and FR: Fusarium redolens.

and VIII) were clustered in TEF group III. Isolates clustered in the RAPD groups IV, V, and VI (Figure 3(a)) were in TEF group IV (Figure $3(\mathrm{~b})$ ), while TEF group $\mathrm{V}$ comprised the same ten isolates as RAPD group IX. The TEF1- $\alpha$ gene region from C4-15 (a representative isolate from RAPD group IX) was subjected to a BlastN enquiry in GenBank, which showed that this isolate had high sequence similarity to F. proliferatum (a single mismatch) and had 100\% similarity with isolate 165PG/F (Accession no. GU066714).

3.3. Bacterial, F. redolens, and Fod Race-Specific PCR Assays. Race-correlated amplifications from $95.45 \%$ of the isolates were obtained using race-specific primers, as described by Chiocchetti et al. [10]. For the 132 isolates, Forty-three and seventy of the isolates produced a $295 \mathrm{bp}$ (diagnostic for race 1 or race 8 ) or a $564 \mathrm{bp}$ (specific for race 2) amplification product, respectively. The $1,315 \mathrm{bp}$ amplification product, corresponding to race 4 , was never detected in the sampled isolates. Thirteen isolates produced race 1 or race 8 band with retarded electrophoretic mobility, while six isolates did not show any amplification signal/band. All isolates are classified in Table 1 by race using race-specific primers. Neither F. redolens nor eubacteria were detected among the tested isolates. Race characterization and presence of specific amplification bands for F. redolens (Figure 4(b)), eubacteria (Figure 4(c)), and certain isolates (Figure 4(a)) are shown in Figure 4.

Isolates C6-14, C6-15, and C7-02 (from RAPD group I and TEF group I, where Fod race 2 tester is included) did not show a race-specific band. Furthermore, seven isolates were distributed in three RAPD groups (RAPD groups IV, V, and VI) that were clustered in the same TEF group (TEF group IV). RAPD group IV (three isolates) did not produce any race-specific band. RAPD group V (only one isolate) showed a typical race 1- or race 8-specific band. RAPD group VI (three isolates) showed an unusual race 1 or race 8 specific band with retarded electrophoretic mobility. Similarly, isolates from RAPD group IX (all included in the TEF group V) showed race 1 or race 8 band with retarded electrophoretic mobility (see isolate C4-15). Certain isolates from those RAPD groups are shown in Figure 4(a).

Isolates C10-07 (RAPD group V), C8-08 (RAPD group VI), and C4-15 (RAPD group IX) and the Fod race 8 tester showed an amplification product (race 1 or race 8 band with retarded electrophoretic mobility, $\sim 295 \mathrm{bp}$ ) only with the race-specific primers Ft3/R8.1. As expected, sequencing of this amplicon (Figure 5) showed that it included the $3^{\prime}$ end of Fot1 transposon and Fot1-flanking genomic region (Fot137, GenBank accession X64799), similar to that observed in the Fod race 8 tester. Moreover, the difference in mobility of the amplified bands from isolates C4-15 and C8-08 could be explained by an additional sequence of 17 nucleotides (CAGGGGGGGTCGGTTAC) located downstream to the $3^{\prime}$ inverted terminal repeat of the Fot1 transposon, which was not observed in the Fod race 8 tester.

As complementary data, to determine whether the Fot1 transposon was moved or the primer target sequences modified, Southern blot analyses using a Fot1-specific probe were performed with two isolates (C6-14 and C6-15), without specific amplification but clustered near the Fod race 2 tester by both phylogenetic analyses. The restriction pattern confirmed that these two isolates had the same restriction pattern as the Fod race 2 tester, therefore confirming that they indeed belonged to Fod race 2 (data not shown).

3.4. Pathogenicity Assay. Given the high number of isolates, a pathogenicity test was conducted with a subset of the population (Table 3) using RAPD analysis as the reference. For this purpose, at least one representative isolate from each RAPD group was selected. Cultivars "Suprema," "Reina," and "Eilat" were susceptible to isolates C5-20, C6-15, C6-25, and C9-10 and race 2 tester but resistant to others (Table 4). But only "Eilat" showed moderate severity when inoculated with race 4 tester. Moreover, the cultivar "Reina" showed lower severity values than cultivars "Suprema" and "Eilat". The opposite was found with the cultivar "New Elsy," which was susceptible to isolates C4-17, C4-22, and C10-14 and to race 1 tester but not race 8 tester. This cultivar could be 


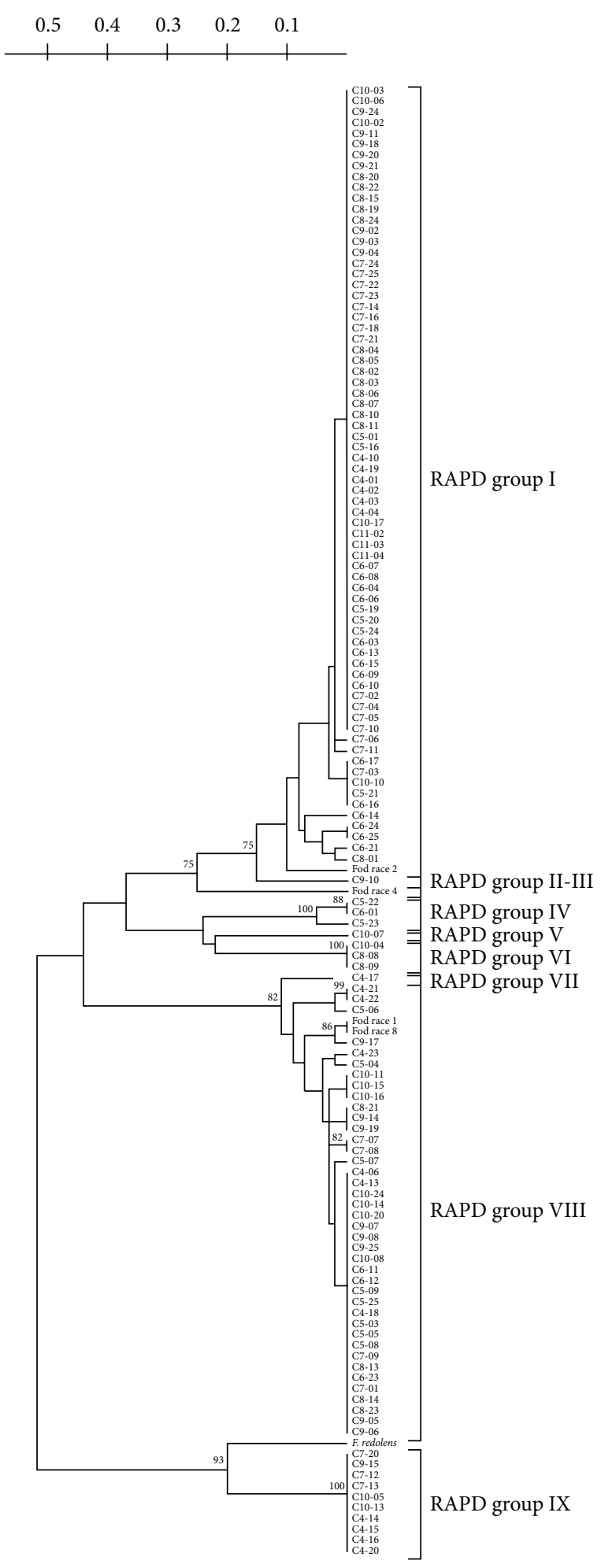

(a)

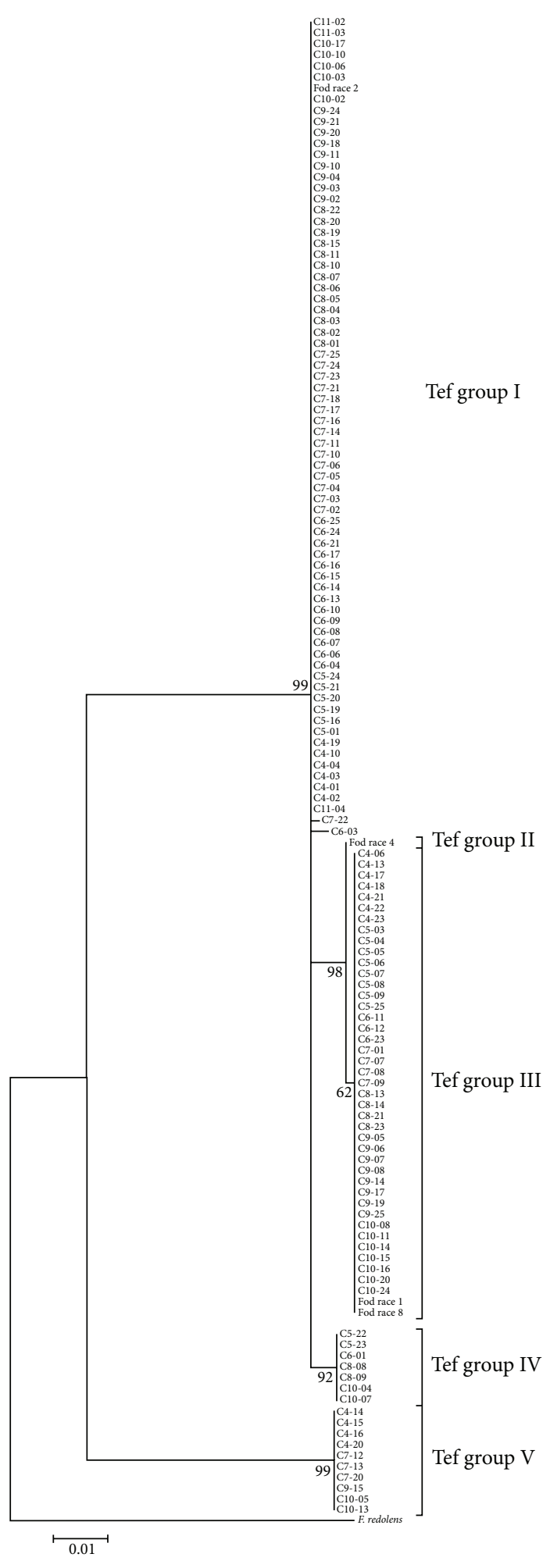

(b)

FIGURE 3: Phylogenetic analyses using molecular tools: (a) cluster analysis of the RAPD data was performed by the UPGMA method. RAPD groups are shown on the right of the tree. (b) Most likelihood trees were generated by TEF1- $\alpha$ gene sequencing. Evolutionary history was inferred from the maximum likelihood method based on the Kimura 2-parameter model. The tree with the highest log-likelihood (-1413.6427) is shown. TEF groups are shown on the right of the tree. The numbers on the branches are values from bootstrap analysis, in percentages, with 100 replications for both types of phylogenetic analyses. 


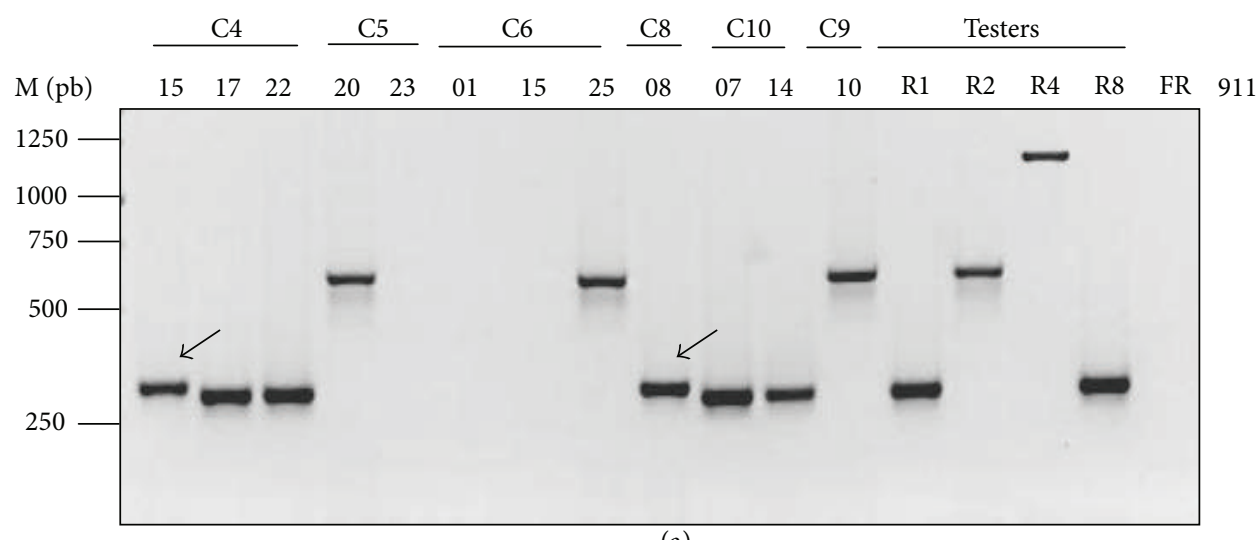

(a)

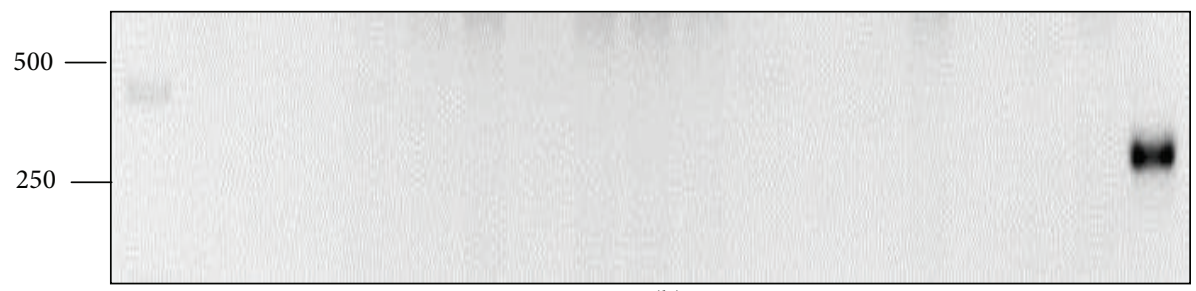

(b)

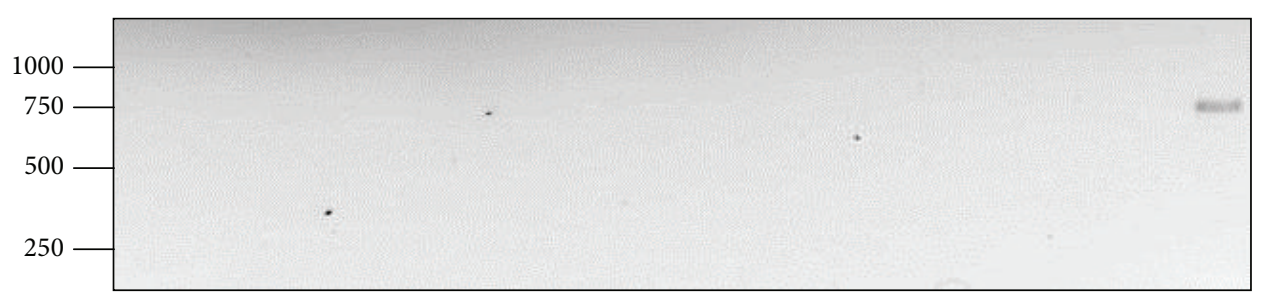

(c)

FIGURE 4: Specific Fod-race primers showing different amplification products. Agarose gel electrophoresis (1.5\%) of PCR products from the genomic DNA of 12 representative RAPD group isolates, four Fod testers, and one Fusarium redolens isolate. (a) Multiplex PCR in which five primers were mixed in the same reaction tube, where combinations of Ft3/R8.1, Ft3/R2.1, and Ft3/R4.2 resulted in bands of 295 (race 1/8), 564 (race 2), and 1315 bp (race 4), respectively; bands with retarded electrophoretic mobility are shown with an arrow. (b) Multiplex PCR products obtained with the LSU (not shown) and Fusarium redolens-specific primers, with a resulting band of $386 \mathrm{bp}$. (c) PCR of the eubacterial primers $704 \mathrm{f}$ and 1495r where a 900 bp product was not amplified. Fod testers R1 (race 1), R2 (race 2), R4 (race 4), and R8 (race 8); Fr: Fusarium redolens and 911 (bacterial tester). M: molecular size marker (1 kb ladder, Biotools); sizes (base pairs) are indicated on the left.

\author{
Isolate $\mathrm{C} 4-15$ \\ Isolate C8-08 \\ Isolate $\mathrm{C} 10-07$ \\ Isolate Fod race8 tester
}

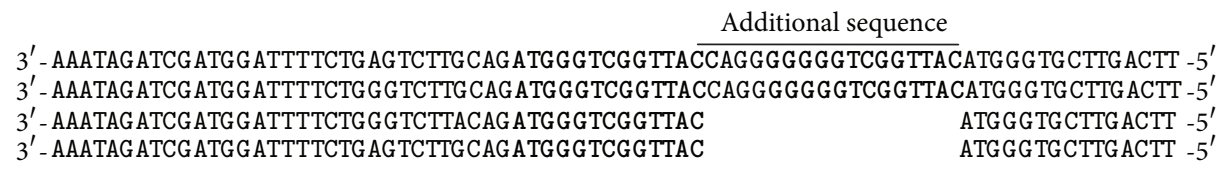

$3^{\prime}$ - AAATAGATCGATGGATTTTCTG AG TCTTGCAGG TGGGTCG GTTACCAGGGGGGGTCGGTTACATGGGTGCTTGACT' -5 '

FIGURE 5: Aligned DNA sequences of the Fot1 final portion and the inverted terminal repeat (ITR) from F. melonis; Fod race 8 (tester) and three isolates from our population, using primers Ft3/R8.1. A sequence complementary to the Fot1 primer in the ITR is displayed in the box. The perfect direct repeats in the ITR are given in bold.

used to differentiate between races 1 and 8. Cultivar "New Elsy," considered resistant to race 2 in our assay conditions showed a moderate severity for C6-15 and C6-25 isolates and a low severity for C5-20 and C9-10. Isolate C6-15 was confirmed to belong to race 2 , as expected from the results of the phylogenetic analyses (Figure 3). The isolates C5-23, C601, C8-08, and C10-07 were not pathogenic to any cultivar, although C10-07 isolate showed 0.19 AUDPC value in "New Elsy." In the cultivar "Mayor," these four isolates did not show severity as opposed to the other isolates and Fod races 1 and 2 testers. This last result agrees with data supported in Table 2. F. proliferatum (isolate C4-15) produced low disease severity in cultivars "Eilat" and "New Elsy," although severity was significantly higher than in the control (data not shown).

3.5. Fod Race Frequency and Prevalence. Taking into account all the data, the frequency and prevalence of each race in the tested area were calculated (Table 5). Regarding frequency, 
TABLE 4: Standardized AUDPC for carnation cultivars.

\begin{tabular}{|c|c|c|c|c|c|c|}
\hline \multirow{2}{*}{$\begin{array}{l}\text { RAPD } \\
\text { Group }\end{array}$} & \multirow{2}{*}{ Isolates/Testers } & \multicolumn{5}{|c|}{ Carnation cultivars } \\
\hline & & Suprema & Reina & New Elsy & Eilat & Mayor \\
\hline I & C5-20 & $0.56(0.02) \mathrm{a}$ & $0.34(0.06) \mathrm{ab}$ & $0.23(0.04) b c$ & $0.67(0.00) \mathrm{a}$ & $0.64(0.02) \mathrm{a}$ \\
\hline I & C6-15 & $0.61(0.06) \mathrm{a}$ & $0.43(0.05) \mathrm{a}$ & $0.31(0.02) \mathrm{b}$ & $0.75(0.02) \mathrm{a}$ & $0.64(0.01) \mathrm{a}$ \\
\hline I & C6-25 & $0.64(0.03) \mathrm{a}$ & $0.45(0.04) \mathrm{a}$ & $0.31(0.07) \mathrm{b}$ & $0.74(0.01) \mathrm{a}$ & $0.62(0.01) \mathrm{a}$ \\
\hline II & C9-10 & $0.54(0.03) \mathrm{a}$ & $0.47(0.03) \mathrm{a}$ & $0.21(0.03) b c$ & $0.65(0.02) \mathrm{a}$ & $0.61(0.03) \mathrm{a}$ \\
\hline IV & C6-01 & $0.07(0.02) \mathrm{bcd}$ & $0.04(0.02) \mathrm{c}$ & $0.10(0.01) \mathrm{cd}$ & $0.05(0.02) c$ & $0.03(0.01) b$ \\
\hline $\mathrm{V}$ & C5-23 & $0.05(0.01) \mathrm{cd}$ & $0.04(0.01) \mathrm{c}$ & $0.13(0.02) c d$ & $0.05(0.05) \mathrm{c}$ & $0.02(0.01) b$ \\
\hline VI & $\mathrm{C} 10-07$ & $0.18(0.06) \mathrm{b}$ & $0.07(0.01) \mathrm{c}$ & $0.19(0.04) b c$ & $0.10(0.01) \mathrm{c}$ & $0.01(0.00) b$ \\
\hline VII & $\mathrm{C} 8-08$ & $0.09(0.02) b c$ & $0.12(0.04) b c$ & $0.14(0.02) \mathrm{cd}$ & $0.05(0.01) \mathrm{c}$ & $0.08(0.03) b$ \\
\hline VIII & $\mathrm{C} 4-17$ & $0.00(0.00) \mathrm{d}$ & $0.00(0.00) \mathrm{c}$ & $0.56(0.04) \mathrm{a}$ & $0.02(0.01) \mathrm{c}$ & $0.63(0.02) \mathrm{a}$ \\
\hline VIII & $\mathrm{C} 4-22$ & $0.01(0.01) \mathrm{cd}$ & $0.02(0.01) c$ & $0.61(0.02) \mathrm{a}$ & $0.02(0.01) \mathrm{c}$ & $0.66(0.02) \mathrm{a}$ \\
\hline IX & $\mathrm{C} 10-14$ & $0.00(0.00) \mathrm{d}$ & $0.02(0.01) \mathrm{c}$ & $0.58(0.00) \mathrm{a}$ & $0.02(0.01) \mathrm{c}$ & $0.55(0.08) \mathrm{a}$ \\
\hline VIII & $\mathrm{R} 1$ & $0.01(0.01) \mathrm{d}$ & $0.03(0.01) \mathrm{c}$ & $0.57(0.02) \mathrm{a}$ & $0.04(0.01) \mathrm{c}$ & $0.54(0.04) \mathrm{a}$ \\
\hline I & $\mathrm{R} 2$ & $0.50(0.06) \mathrm{a}$ & $0.37(0.04) \mathrm{a}$ & $0.13(0.04) \mathrm{cd}$ & $0.63(0.02) \mathrm{a}$ & $0.59(0.03) \mathrm{a}$ \\
\hline III & $\mathrm{R} 4$ & $0.00(0.00) \mathrm{d}$ & $0.13(0.08) \mathrm{c}$ & $0.06(0.02) \mathrm{d}$ & $0.41(0.11) b$ & $0.06(0.03) b$ \\
\hline VIII & $\mathrm{R} 8$ & $0.06(0.01) \mathrm{bcd}$ & $0.05(0.04) \mathrm{c}$ & $0.17(0.01) b c$ & $0.01(0.01) \mathrm{c}$ & $0.07(0.05) b$ \\
\hline
\end{tabular}

Each cultivar was infested using a root-dipping technique in a solution with $10^{6}$ conidia $\mathrm{mL}^{-1}$ from each isolate. Testers isolates: R1, Fod race 1; R2, Fod race 2; R4, Fod race 4; and R8, Fod race 8. For each cultivar (columns), numbers with the same letter were not significantly different according to Tukey's test at $P<0.05$. In parentheses, SE of the mean $(n=5)$.

TABLE 5: Frequency and prevalence of each race by PCR using specific primers and TEF1- $\alpha$ gene.

\begin{tabular}{|c|c|c|c|c|c|c|c|c|c|}
\hline \multicolumn{6}{|c|}{ Specific primers } & \multicolumn{4}{|c|}{ TEF1- $\alpha$} \\
\hline \multirow[t]{2}{*}{ Races } & \multicolumn{2}{|c|}{ Frequency } & \multicolumn{2}{|c|}{ Prevalence ${ }^{a}$} & \multirow[t]{2}{*}{ Groups } & \multicolumn{2}{|c|}{ Frequency } & \multicolumn{2}{|c|}{ Prevalence } \\
\hline & $\mathrm{Ib}$ & $\mathrm{Ib} / \mathrm{Ti}$ & $F$ & $F / \mathrm{tF}$ & & Ip & $\mathrm{Ip} / \mathrm{Ti}$ & $F$ & $F / \mathrm{tF}$ \\
\hline Race $1-8$ & 42 & $31.8 \%$ & 21 & $38.9 \%$ & III & 41 & $31.1 \%$ & 20 & $37.0 \%$ \\
\hline Race 2 & 71 & $53.8 \%$ & 31 & $57.4 \%$ & I & 74 & $56.1 \%$ & 32 & $59.3 \%$ \\
\hline $\begin{array}{l}\text { Retarded } \\
\text { band }\end{array}$ & 13 & $9.8 \%$ & & & $\mathrm{~V}(\mathrm{Fp})$ & 10 & $7.6 \%$ & 6 & $11.1 \%$ \\
\hline
\end{tabular}

aPrevalence was expressed as the ratio "number of farms in which a specific race was found/total farm numbers," as a percentage.

Ib: Isolates with race-specific amplified band

Ip: Isolates using TEF grouping

Ti: Total isolates $(n=132)$

$F$ : Numbers of farms in which a specific race F. proliferatum or TEF group was found

tF: Total farms $(n=54)$

Fp: Fusarium proliferatum.

using Fod-specific primers, 31.8\% (41 isolates plus C10-07) and $53.8 \%$ (71 isolates) of the total population belonged to race 1 or race 8 and race 2 , respectively. Thirteen of the 132 isolates showed a retarded band, where ten of these could be ascribed to F. proliferatum. RAPD-PCR and TEF1- $\alpha$ analysis showed similar results. The TEF1- $\alpha$ analyses identified $31.1 \%$ (41 isolates) and 56.1\% (71 isolates plus C6-14, C6-15, and C702 ) of the total population to belong to race 1 or race 8 and race 2 , respectively.

In this study, 54 farms in 25 zones (Table 1) were sampled. Analysis with specific primers showed a prevalence of $38.9 \%$ and $57.4 \%$ for race 1 or race 8 and race 2 , respectively. Phylogenetic analysis showed a different prevalence, $37.0 \%$ and $59.3 \%$ for race 1 or race 8 and race 2 , respectively.

Fod race 2 and race 1 or race 8 were located together in 10 zones, but their concurrent presence was found on only one farm (11b, Table 1). Moreover, 11 zones displayed only Fod race 2, while 4 zones had only Fod races 1 or 8 , indicating that Fod race 2 was spatially more widespread than Fod race 1 or race 8 in the studied area. The presence of $F$. proliferatum was independent from that of pathogenic Fod races (farms $4 \mathrm{~b}$, $10 \mathrm{c}, 11 \mathrm{c}$, and 22a). Isolates without specific band amplification grouping in RAPD group IV (C5-22, C5-23, and C6-01) were found on the same farm (9a) together with race 1 or race 8 isolate (C5-25). Isolate C10-07, which showed a specific Fod race 1 or race 8 amplification, was found on a farm, coexisting with $F$. proliferatum (22a). RAPD group VI was identified on two farms (7f, 17a) coexisting with Fod race 2 isolates. Isolates without the race 2-specific amplicon (C6-14, C6-15, and C702 ) were found on the same farm (7c).

\section{Discussion}

4.1. Racial Frequency and Prevalence in the Studied Population. We conclude that Fod race 2 was the most frequent and prevalent in the study area, followed by race 1 or race 8 , 
which is consistent with another study in the same region [5]. However, the previous report detected a much lower frequency of race 1 than that reported here for 1 or 8 . Earlier Fod race diversity reports in other Spanish regions have confirmed frequent and widespread distribution of Fod race 2 in carnation crops $[9,31]$. However, race 8 has not been documented in Spain [5, 9, 31]. Genetic variation studies in this region have previously shown a race structure similar to that encountered worldwide $[2,3,32]$. Based on these data, carnations cultivars with resistance to race 2 and races 1 and 8 are the most recommended in the studied area.

4.2. Molecular Tools: RAPD-PCR, Sequencing of the TEF1- $\alpha$ Gene, and Diagnosis of the Fod Race-Specific Primers. Among the diagnostic protocols for Fusarium species, PCR assays are considered to be one of the most rapid and reliable methods [33]. RAPD fingerprinting and TEF1- $\alpha$ sequence analyses showed strikingly similar and well-resolved clades for Fod races, both approaches complementing each other. Several studies have applied RAPD fingerprinting to identify all major races of Fod present in other countries $[4,11]$. Regarding sequence data, the TEF1- $\alpha$ gene has been resolved as the most phylogenetically reliable molecular marker of the Fusarium genus, relative to the $\beta$-tubulin gene, ITS regions, and CYP51C gene [14]. Our study demonstrated that TEF1- $\alpha$ could be used as a molecular marker to group Fod isolates into races, this method taking less time and being more reliable than RAPD-PCR. Indeed, a previous report revealed a higher level of homoplasy shown by RAPDbased phylogeny than the TEF1- $\alpha$ and mtSSU rDNA gene sequencing data, using F. oxysporum from maize [12]. The high genetic homogeneity within the races found in this population was consistent with that reported in earlier studies $[3,32]$.

We propose that PCR with specific primers, whose amplification is related with the Fot1-transposable element [10], is not sufficient to confirm the presence of Fod in a given area, due to differences in the target genomic sequences. Indeed, these markers showed variable specificity in our population, as described in a previous study [5]. As an example, 13 isolates showed a retarded Fod race 1 or race 8 band when the specific primers were used. Moreover, Fot 1 elements exhibit a very low level of polymorphism in the Fusarium oxysporum complex [34]. Our data using race-specific primers showed that Fod race 8 (and probably Fod race 1) has 17 nucleotides less in this region than other Fusarium species. A possible horizontal transfer of Fot1 transposon between Fusarium species [34] could create a deletion in this region, differentiating isolates related to Fod from the others (i.e., Fusarium proliferatum and F. oxysporum isolate C8-08).

Although molecular techniques were reliable, they must be validated with a phenotypic pathogenicity test. Despite the reasonable degree of disease severity found in the pathogenicity test, the assay showed results that were not expected; for example, susceptible responses in New Elsy and Eilat to race 2 and race 4, respectively. Pathogenicity tests conducted in semicontrolled conditions by Ben-Yephet and Shtienberg [35] indicated that the carnation response to Fod is substantially influenced by environmental conditions (mainly solar radiation, temperature, and substrate), which could explain the observed results.

4.3. Pathogenicity Test. In our pathogenicity test, the isolate C6-15 (which did not show a Fod race 2-specific band) behaved like Fod race 2 and was as virulent as other race 2 isolates, such as C6-14 and C7-02. Southern blot analysis (using Fot1 transposon as the probe) showed that two isolates generated the same restriction pattern as the Fod race 2 tester (data not shown [10]), suggesting that the absence of specific amplification was not due to a movement of Fot1 but due to a change in the target sequences of these primers. Thus, we propose that the presence of these isolates (C6-14, C6-15, and C7-02) in the population could form a possible Fod race 2 subgroup. To define subgroups within Fod race 2 an extensive virulence study of isolates would have to be carried out.

Isolates selected from the seven clustered in RAPD groups IV, V, and VI and TEF group IV did not show severity in any of the carnation cultivars tested. These isolates, recovered on different farms from wilted carnations, were characterized as F. oxysporum by TEF1- $\alpha$ sequencing. They may be saprophytic F. oxysporum, possibly associated with the carnation rhizosphere, as found in previous studies [4].

Ten isolates (7.6\% of the collection) belonging to F. proliferatum (RAPD group IX and TEF group V) were found to be nonpathogenic in our phenotypic assay. In a similar study, seven nonpathogenic isolates of $F$. proliferatum, obtained from carnation crops in Italy, Israel, and the Netherlands were clearly recognized on the basis of their RAPD fingerprint [4]. However, Aloi and Baayen [2] obtained 11 isolates of F. proliferatum belonging to a distinct vegetative compatibility groups from Fod, which were associated with the basal rot of carnation. This fungus has also been identified as a pathogen in asparagus [36] and as an opportunistic fungus in wheat [37] and palms [13].

\section{Conclusions}

In conclusion, population characterization showed that Fod race 2 was widely distributed along the north-west of Cádiz, followed by race 1 or race 8 . Molecular techniques, such as TEF1- $\alpha$ sequencing or RAPD-PCR, allowed (mainly the former) a better identification and clustering of different Fod races than using Fod race-specific primers. Indeed, isolates failing to generate an amplification signal with Fod racespecific primers may indicate the presence of a Fod race 2 subgroup in this area.

\section{Conflict of Interests}

The authors declare that there is no conflict of interests regarding the publication of this paper.

\section{Acknowledgments}

This research was supported by Grants from the Ministerio de Educación y Ciencia (AGL2005-08137-C03-02), Consejería de Innovación, Ciencia y Empresa de la Junta de Andalucía 
(P06-AGR-02313), and the Ministerio de Ciencia e Innovación (AGL2008-05414-C03-01) of Spain. The authors thank Q. Migheli for critically reading the manuscript and making valuable suggestions prior to submission and Drs. E.T. Steenkamp and J. M. Melero-Vara for providing F. redolens and reference strains of Fod. The authors also thank M.L. Castillo and S. Castillo for their excellent technical assistance.

\section{References}

[1] M. Bogale, B. D. Wingfield, M. J. Wingfield, and E. T. Steenkamp, "Species-specific primers for Fusarium redolens and a PCR-RFLP technique to distinguish among three clades of Fusarium oxysporum," FEMS Microbiology Letters, vol. 271, no. 1, pp. 27-32, 2007.

[2] C. Aloi and R. P. Baayen, "Examination of the relationships between vegetative compatibility groups and races in Fusarium oxysporum f. sp. dianthi," Plant Pathology, vol. 42, no. 6, pp. 839850, 1993.

[3] R. P. Baayen, F. van Dreven, M. C. Krijger, and C. Waalwijk, "Genetic diversity in Fusarium oxysporum f. sp. dianthi and Fusarium redolens f. sp. dianthi," European Journal of Plant Pathology, vol. 103, no. 5, pp. 395-408, 1997.

[4] Q. Migheli, E. Briatore, and A. Garibaldi, "Use of random amplified polymorphic DNA (RAPD) to identify races 1, 2, 4 and 8 of Fusarium oxysporum f. sp. dianthi in Italy," European Journal of Plant Pathology, vol. 104, no. 1, pp. 49-57, 1998.

[5] A. M. Prados-Ligero, M. J. Basallote-Ureba, C. J. López-Herrera, and J. M. Melero-Vara, "Evaluation of susceptibility of carnation cultivars to Fusarium Wilt and determination of Fusarium oxysporum f. sp. dianthi races in Southwest Spain," HortScience, vol. 42, no. 3, pp. 596-599, 2007.

[6] Anonymous, Anuario de Estadística Agroalimentaria. Cap. 20:20.7.2.3, Ministerio de Medio Ambiente y Medio Rural y Marino, Madrid, Spain, 2008.

[7] J. A. Navas Becerra, Apuntes sobre el cultivo del clavel. Consejería de Agricultura y Pesc, Junta de Andalucía, Sevilla, Spain, 1988.

[8] A. García Ruiz, M. de Cara, M. Santos, and J. C. Tello, "Fusarium wilt of carnation in northwestern coast of Cádiz (Spain)," Boletín de Sanidad Vegetal, vol. 35, pp. 317-328, 2009.

[9] J. L. Andrés, M. J. Vicente, J. L. Cenis et al., "Genetic and pathogenic variation of Fusarium oxysporum f. sp. dianthi in Spain," Boletín de Sanidad Vegetal. Plagas, vol. 27, pp. 249-257, 2001.

[10] A. Chiocchetti, I. Bernardo, M. Daboussi et al., "Detection of Fusarium oxysporum f. sp. dianthi in Carnation tissue by PCR amplification of transposon insertions," Phytopathology, vol. 89, no. 12, pp. 1169-1175, 1999.

[11] S. Manulis, N. Kogan, M. Reuven, and Y. Ben-Yephet, "Use of the RAPD technique for identification of Fusarium oxysporum f. sp. dianthi from carnation," Phytopathology, vol. 84, no. 1, pp. 98-101, 1994.

[12] K. O’Donnell, H. C. Kistlerr, E. Cigelnik, and R. C. Ploetz, "Multiple evolutionary origins of the fungus causing panama disease of banana: Concordant evidence from nuclear and mitochondrial gene genealogies," Proceedings of the National Academy of Sciences of the United States of America, vol. 95, no. 5, pp. 20442049, 1998.

[13] M. L. Elliott, E. A. Des Jardin, K. O’Donnell, D. M. Geiser, N. A. Harrison, and T. K. Broschat, "Fusarium oxysporum f. sp. palmarum, a novel forma specialis causing a lethal disease of syagrus romanzoffiana and Washingtonia robusta in Florida," Plant Disease, vol. 94, no. 1, pp. 31-38, 2010.

[14] D. Fernández-Ortuño, E. Loza-Reyes, S. L. Atkins, and B. A. Fraaije, "The CYP51C gene, a reliable marker to resolve interspecific phylogenetic relationships within the Fusarium species complex and a novel target for species-specific PCR," International Journal of Food Microbiology, vol. 144, no. 2, pp. 301-309, 2010.

[15] D. M. Geiser, M. D. M. Jiménez-Gasco, S. Kang et al., "FUSARIUM-ID v. 1.0: a DNA sequence database for identifying Fusarium," European Journal of Plant Pathology, vol. 110, no. 5-6, pp. 473-479, 2004.

[16] N. Shafagh, M. F. Rastegar, and B. Jafarpour, "Physiological race and genetic diversity determination of Fusarium oxysporum $\mathrm{f}$. sp. melonis by differential hosts and molecular marker RAPD in Northern and Razavi Khorasan provinces," Research Journal of Biological Sciences, vol. 3, pp. 790-793, 2008.

[17] F. M. Alves-Santos, L. Cordeiro-Rodrigues, J. M. Sayagués et al., "Pathogenicity and race characterization of Fusarium oxysporum $f$. sp. phaseoli isolates from Spain and Greece," Plant Pathology, vol. 51, no. 5, pp. 605-611, 2002.

[18] A. Garibaldi and M. L. Gullino, "Fusarium wilt of carnation: present situation, problems and perspectives," Acta Horticulturae, vol. 216, pp. 45-54, 1987.

[19] O. D. Dhingra and J. B. Sinclair, Basic Plant Pathology Methods, Lewis, Boca Raton, Fla, USA, 2nd edition, 1995.

[20] L. L. Singleton, J. D. Mihail, and C. M. Rush, Methods for Research on Soil-Borne Phytopathogenic Fungi, American Phytopathological Society Press, St Paul, Minn, USA, 1992.

[21] A. Cassago, R. A. Panepucci, A. M. T. Baião, and F. HenriqueSilva, "Cellophane based mini-prep method for DNA extraction from the filamentous fungus Trichoderma reesei," BMC Microbiology, vol. 2, article 1, 2002.

[22] C. Carbonell, D. Cifuentes, J. Tello, and J. L. Ceñis, "Differentiation of Fusarium oxysporum f. sp. lycopersici and F.o. f. sp. radicis-lycopersici and its detection in plant by RAPD markers," Boletín de Sanidad Vegetal Plagas, vol. 20, pp. 919-926, 1994.

[23] D. J. Vakalounakis and G. A. Fragkiadakis, "Genetic diversity of Fusarium oxysporum isolates from cucumber: differentiation by pathogenicity, vegetative compatibility, and RAPD fingerprinting," Phytopathology, vol. 89, no. 2, pp. 161-168, 1999.

[24] Z. Q. Zhou and Y. N. Li, “The RAPD evidence for the phylogenetic relationship of the closely related species of cultivated apple," Genetic Resources and Crop Evolution, vol. 47, no. 4, pp. 353-357, 2000.

[25] W. Link, C. Dixkens, M. Singh, M. Schwall, and A. E. Melchinger, "Genetic diversity in European and Mediterranean faba bean germ plasm revealed by RAPD markers," Theoretical and Applied Genetics, vol. 90, no. 1, pp. 27-32, 1995.

[26] Y. Van De Peer and R. De Wachter, "Treecon for windows: a software package for the construction and drawing of evolutionary trees for the microsoft windows environment," Bioinformatics, vol. 10, no. 5, pp. 569-570, 1994.

[27] S. Kumar, J. Dudley, M. Nei, and K. Tamura, "MEGA: a biologist-centric software for evolutionary analysis of DNA and protein sequences," Briefings in Bioinformatics, vol. 9, no. 4, pp. 299-306, 2008.

[28] M. Kimura, "A simple method for estimating evolutionary rates of base substitutions through comparative studies of nucleotide sequences," Journal of Molecular Evolution, vol. 16, no. 2, pp. 111$120,1980$. 
[29] V. Bianciotto, C. Bandi, D. Minerdi, M. Sironi, H. V. Tighy, and P. Bonfante, "An obligately endosymbiotic mycorrhizal fungus itself harbors obligately intracellular bacteria," Applied and Environmental Microbiology, vol. 62, no. 8, pp. 3005-3010, 1996.

[30] R. P. Baayen and C. H. van der Plas, "Localization ability, latent period and wilting rate in eleven carnation cultivars with partial resistance to Fusarium wilt," Euphytica, vol. 59, no. 2-3, pp. 165174, 1992.

[31] V. Cebolla, C. Monton, P. Carrasco, and A. Rodríguez, La importancia de las razas I y II de Fusarium oxysporum $f_{s p}$. dianthi en los suelos españoles, Jornadas sobre Patología Vegetal. Monografía INIA 48, Ministerio de Agricultura, Pesca y Alimentación (ed.), Madrid, Spain, 1983.

[32] G. Lori, V. Edel-Hermann, N. Gautheron, and C. Alabouvette, "Genetic diversity of pathogenic and nonpathogenic populations of Fusarium oxysporum isolated from carnation fields in Argentina," Phytopathology, vol. 94, no. 6, pp. 661-668, 2004.

[33] B. Lievens, M. Rep, and B. P. H. J. Thomma, "Recent developments in the molecular discrimination of formae speciales of Fusarium oxysporum," Pest Management Science, vol. 64, no. 8, pp. 781-788, 2008.

[34] M. J. Daboussi, J. Davière, S. Graziani, and T. Langin, "Evolution of the Fot1 transposons in the genus Fusarium: discontinuous distribution and epigenetic inactivation," Molecular Biology and Evolution, vol. 19, no. 4, pp. 510-520, 2002.

[35] Y. Ben-Yephet and D. Shtienberg, "Effects of the host, the pathogen, the environment and their interactions, on fusarium wilt in carnation," Phytoparasitica, vol. 25, no. 3, pp. 207-216, 1997.

[36] E. Yergeau, M. Filion, V. Vujanovic, and M. St-Arnaud, "A PCRdenaturing gradient gel electrophoresis approach to assess Fusarium diversity in asparagus," Journal of Microbiological Methods, vol. 60, no. 2, pp. 143-154, 2005.

[37] S.-I. Kwon, C. D. Von Dohlen, and A. J. Anderson, "Gene sequence analysis of an opportunistic wheat pathogen, an isolate of Fusarium proliferatum," Canadian Journal of Botany, vol. 79, no. 9, pp. 1115-1121, 2001. 

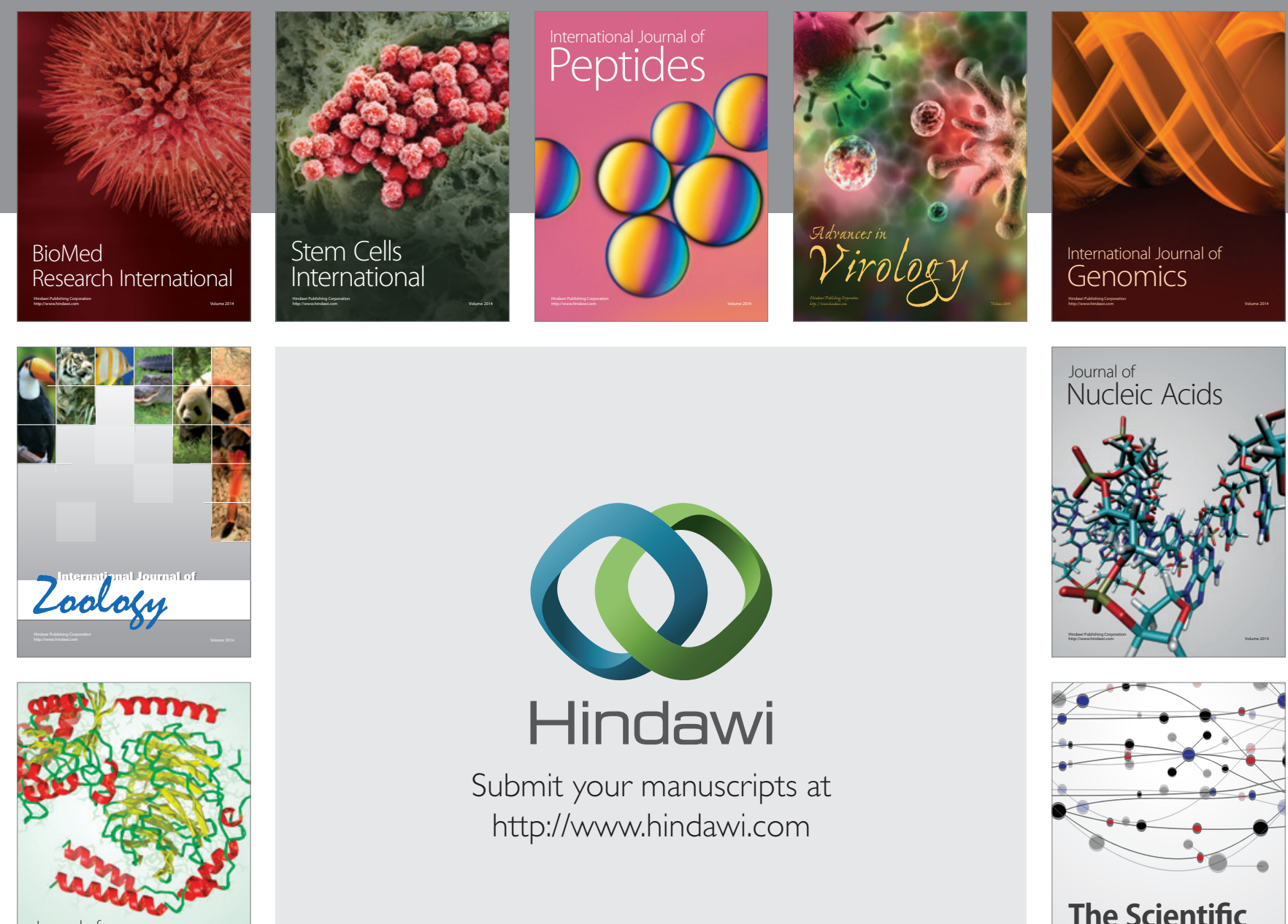

Submit your manuscripts at

http://www.hindawi.com

Journal of
Signal Transduction
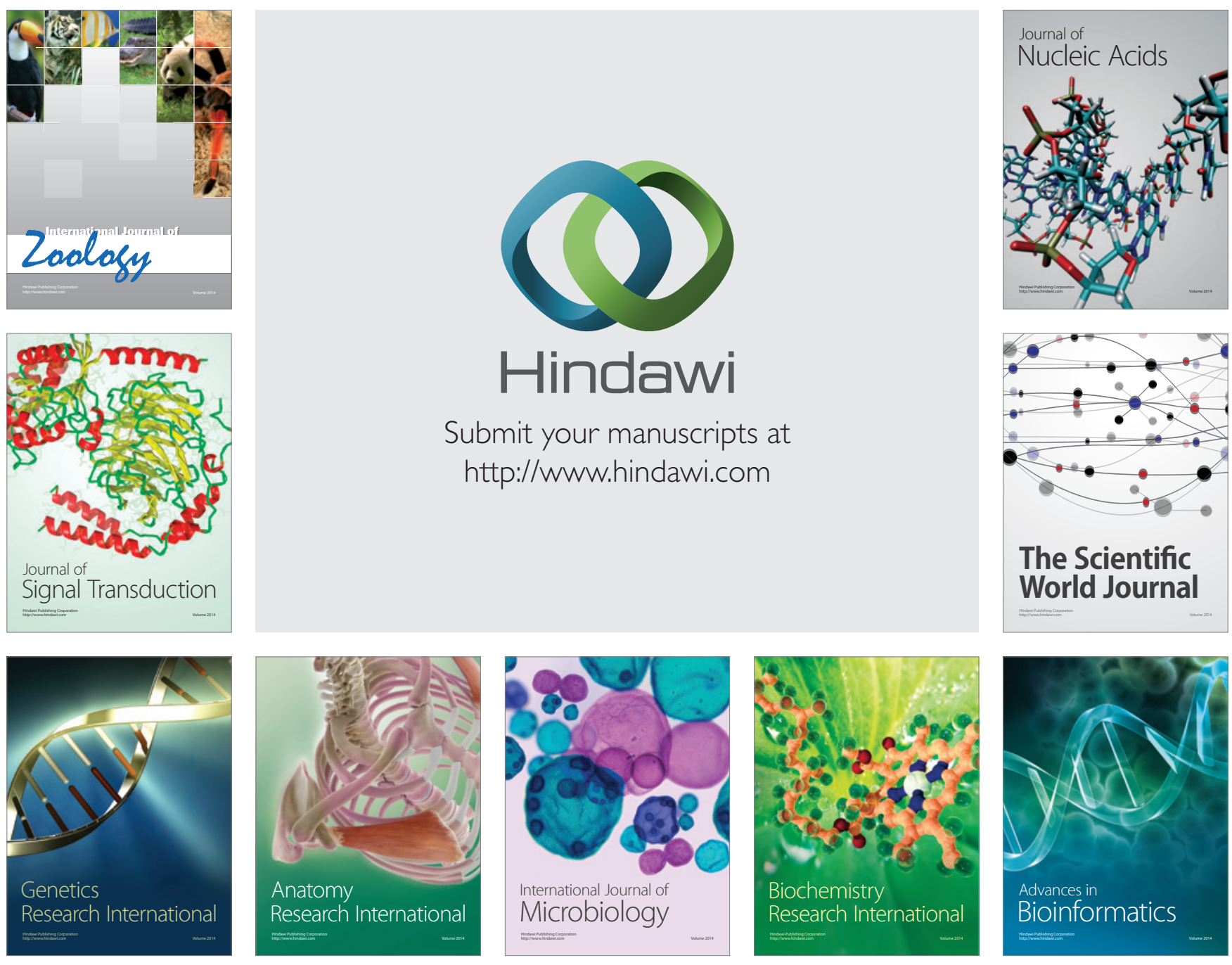

The Scientific World Journal
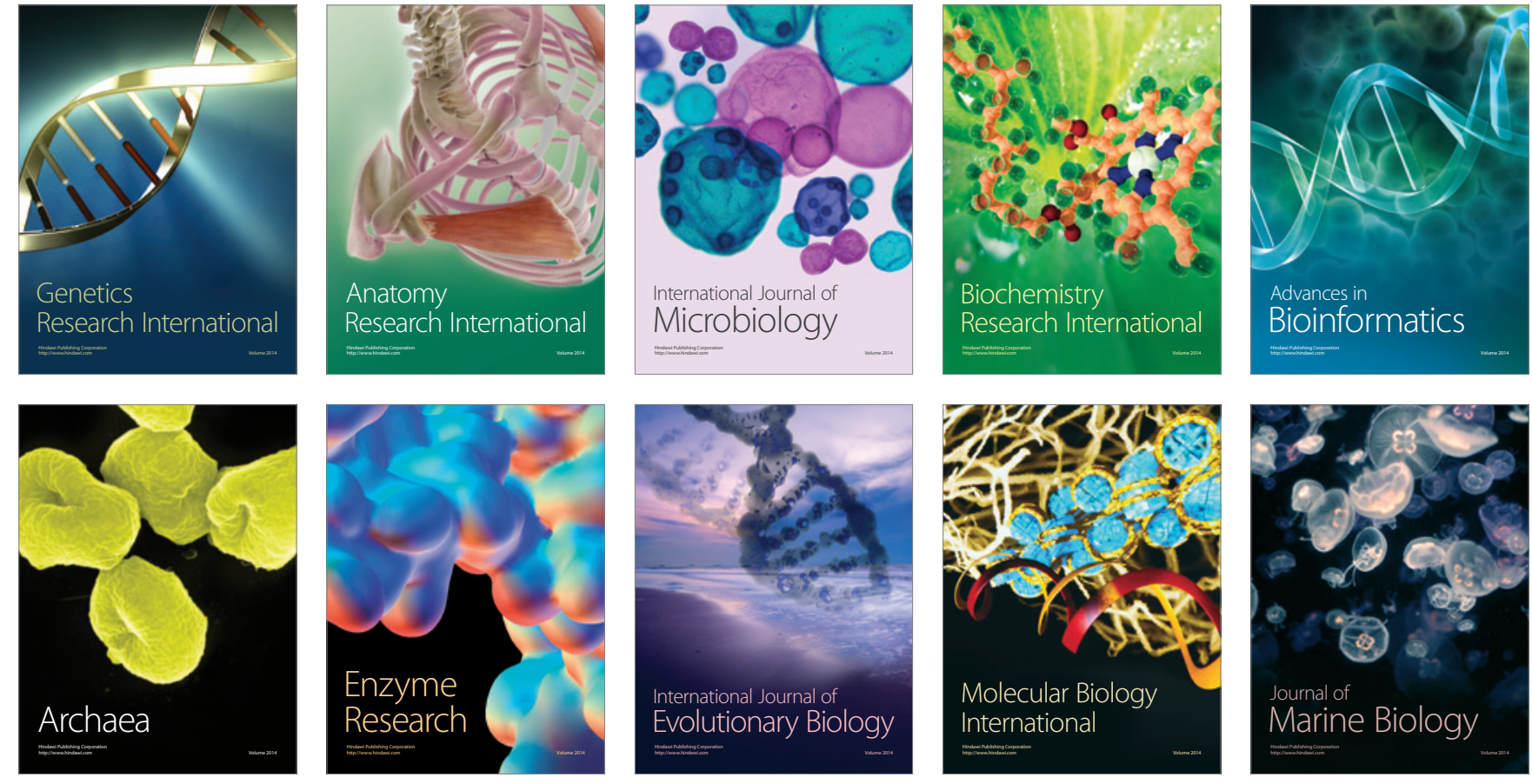